\title{
Re-writing the Script: Decoding the textual experience in the Bronze Age Levant (c.2000-1150 BC)
}

\author{
Rachael Thyrza Sparks \\ University College London
}

\begin{abstract}
Introduction
A review of the types of writing found in the Southern Levant during the Middle and Late Bronze Ages underlines one fact: textual evidence is much rarer in this region than contemporary Egypt, Syria-Lebanon or Mesopotamia. There is a dearth of significant deposits of clay tablet archives or sealings, and the organic materials on which so much ancient writing was probably carried out, such as wood, leather and imported papyrus are only rarely preserved. Even within the materials that have survived, there are further problems with chronology and context, as many examples are poorly provenanced, making it difficult to pinpoint exactly when various developments in palaeography or technique took place. The fact that these data are both statistically insignificant and heavily biased towards certain types of materials makes it something of a challenge to establish how and when different types of script were introduced into the area and the ways in which they were subsequently used, and there is the constant risk that we may have to 'rewrite' our understanding of these processes as fresh evidence comes to hand. Most studies that have been done on writing in the region have been quite specialised, focusing on particular scripts and tending to concentrate on aspects of language rather than the way in which writing is created and used. In particular, the material aspects of this technology have rarely been addressed. This has served to obscure its overall range and diversity.

There are currently around 61 cuneiform texts attributable to the Bronze Age (recording Sumerian, Akkadian, and West Semitic languages; Horowitz et al. 2006), three in alphabetic cuneiform, some 17 Proto-Canaanite examples (Sass 1988; Hamilton 2006; 2010), six in Hittite hieroglyphic (Singer 1977; 1993; 2003) and two probable examples of Aegean scripts (this figure
\end{abstract}

\section{How to cite this book chapter:}

Sparks, R. T. 2013. Re-writing the Script: Decoding the textual experience in the Bronze Age Levant (c.2000-1150 BC). In: Piquette, K. E. and Whitehouse, R. D. (eds.) Writing as Material Practice: Substance, surface and medium. Pp. 75-104. London: Ubiquity Press. DOI: http:// dx.doi.org/10.5334/bai.e 


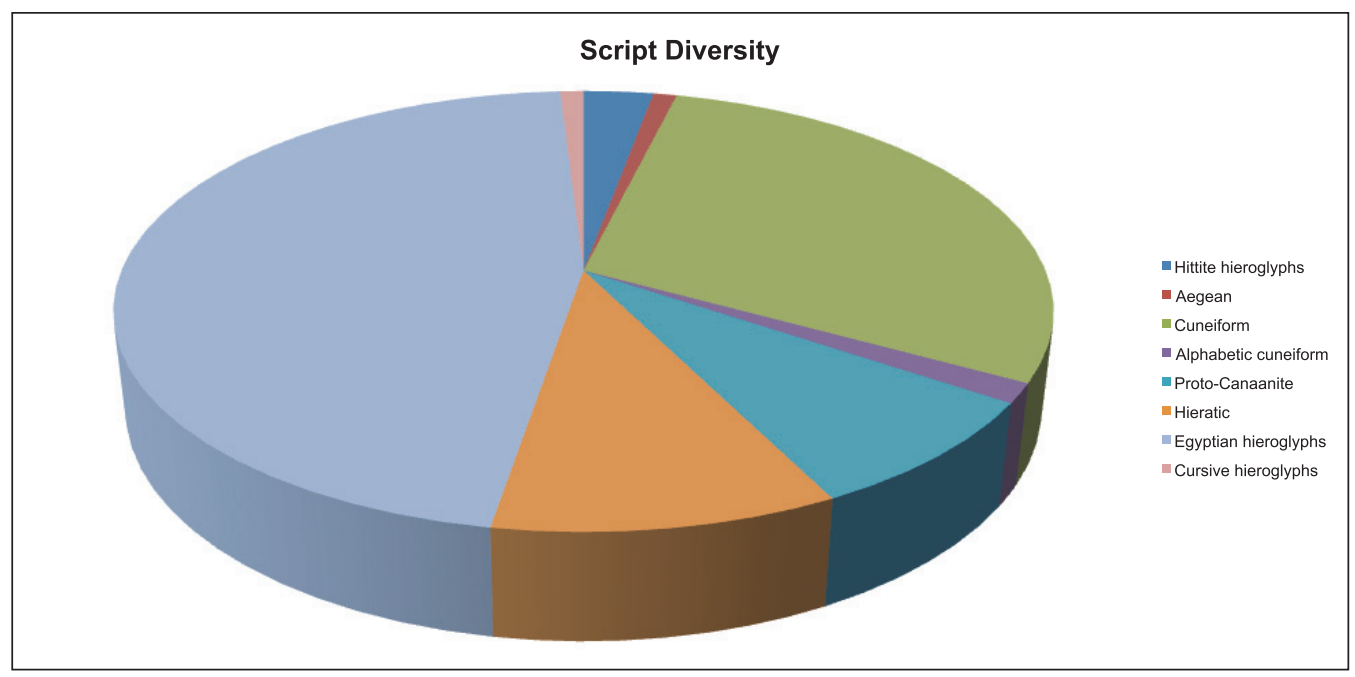

Figure 1: Script diversity in the Southern Levant c.2000-1150 BC. This data excludes pot marks and hieroglyphic-shaped amulets, as it is debatable whether these functioned as writing rather than as symbols or markers. It also excludes hieroglyphic and pseudo-hieroglyphic scarab and seal inscriptions, because the quantity of objects involved would be overwhelming and obscure other patterns in the material.

excludes pot-marks based on the known Cypro-Minoan syllabary, as their identification as writing can be questioned: Cross and Stager 2006; Dothan 1979: 12, fig. 15). Hieratic is represented by at least 21 objects. However the most common group of texts are in Egyptian hieroglyphic; at least 118 examples are known, across a wide range of object types, and the figure explodes into the thousands if one includes the texts moulded or incised onto personal scarabs. Two examples of the less common cursive form of hieroglyphic complete the known repertoire of script forms. No single catalogue of either hieratic or hieroglyphic texts from the region has ever been published, but various studies have dealt with differing aspects of both (Eggler and Keel 2006; Goldwasser 1984; Keel 1997; Maeir et al. 2004; Mumford 1998; Porter and Moss 1952; Sweeney 2004). A summary of script and language diversity may be found in Figures 1-2.

While the linguistic demands of each speciality make a focus on individual scripts understandable, it is worth revisiting the phenomenon of writing in the region in a more holistic fashion, considering what archaeology can contribute to current debate through a study of the materiality of script use, and how this relates to the needs of different individuals and communities. This perspective raises new questions, including what types of materials and objects are used to carry writing, how script size, shape, location and so on inform use and meaning, where such inscribed objects are found, and what these material features and archaeological contexts can tell us about who is using them.

In Middle Bronze Age Canaan, the evidence for use of script is both limited, and mixed in nature. Cuneiform is poorly represented by discoveries of clay tablets at sites such as Hazor and Shechem, clay liver models and appearances on a ceramic jug, and on stone and clay cylinder seals of this period (Horowitz et al. 2006: 46, 65-80, 83-85, 88-91, 95, 121-123). The technique of execution depends on the material being utilised; signs are generally impressed on clay and incised into stone. An exception is a ceramic jug from Hazor, where a cult symbol was drawn in the clay before firing and an Akkadian personal name scratched into the surface afterwards (Horowitz et al. 2006: 65-66). The former points to an intent to use the vessel for cult purposes at the point of production, while the latter points to additional customisation at some later stage. 


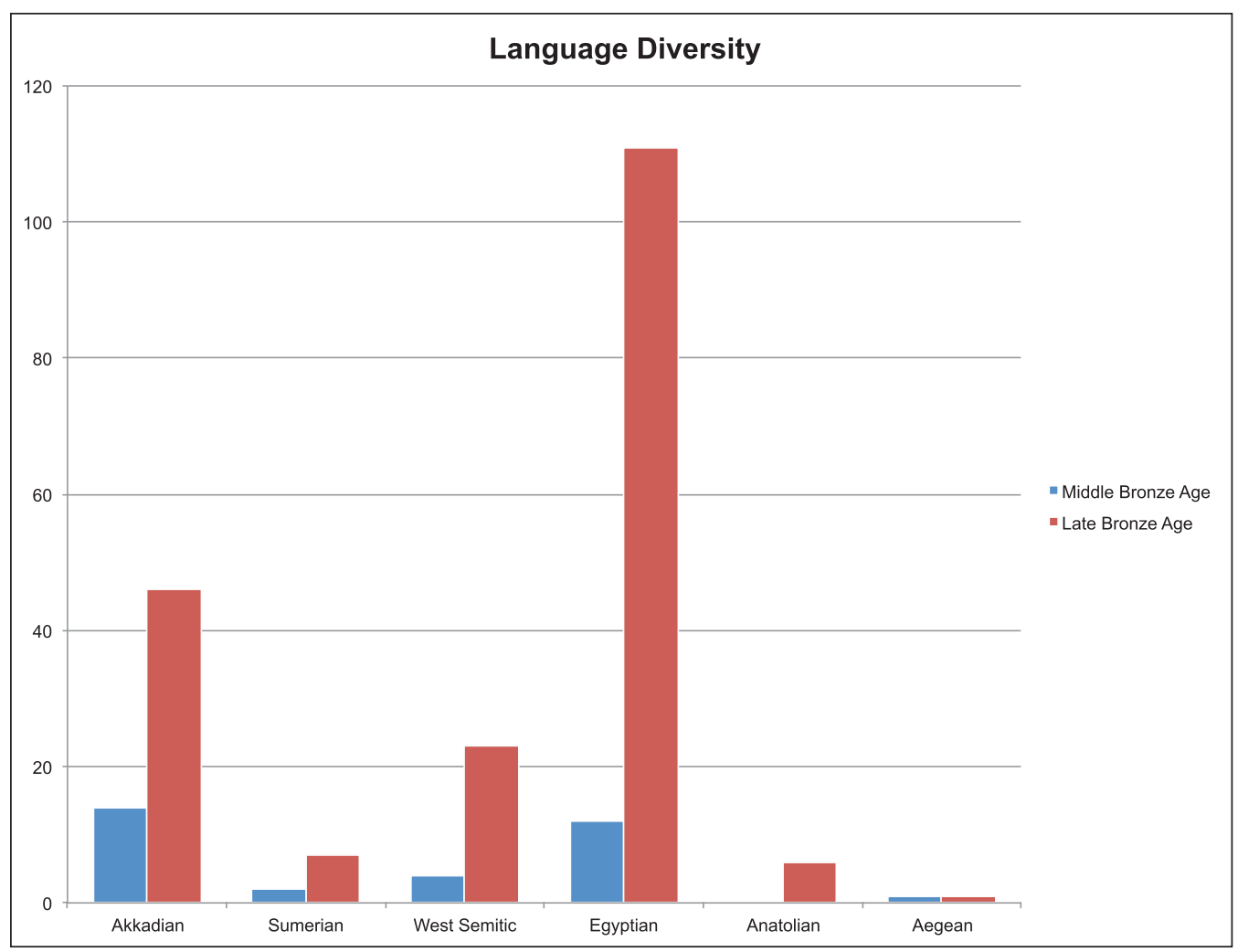

Figure 2: The diversity of languages represented by Bronze Age texts found in the Southern Levant.

Proto-Canaanite appears sporadically, incised and impressed onto ceramic vessels before firing and cut into the surface of a bronze dagger (Sass 1988: figs 140, 143, 271), and there is a single Minoan graffito on a sherd from Tel Haror (Oren et al. 1996). Egyptian hieroglyphic texts of this period are best represented on scarabs and are usually carved into the surface; there are also a few clay bullae, a carnelian bead and a faience cylinder seal (Giveon 1985: 108, no. 138; Keel 1997: 116, cat. 39; Petrie 1930: pl. 10, no. 111; Ussishkin 2004: fig. 23.40.2). Inscribed stone statuary produced at this time would appear to have been looted from Egypt and brought to Canaan at a later date (Weinstein 1975). Cursive hieroglyphs or hieratic script do not yet appear to have been introduced to the region.

During the Late Bronze Age the frequency and range of both scripts and language increases, as does the variety of objects on which text appears. When Canaan was conquered and incorporated into the Egyptian empire, a process formalised with the introduction of Egyptian administrative control during the reign of Tuthmes III (1479-1429 вС), the result was both to reinforce already existing markets for use of writing and to create a whole series of new audiences. Particularly important with regard to the latter was the need to provide efficient communication between Egypt and her new vassals. The language and script of international diplomacy, Akkadian cuneiform, already in use between Near Eastern governments, was now pressed into use for communication with Egypt as well, by means of the traditional clay tablet (Goren et al. 2004; Millard 1999: 317-318, figs 1-2; Moran 1992).

At the same time, changes in the way the region was managed led to the establishment of Egyptianrun garrisons and administrative centres at key locations, such as Gaza, Deir el-Balah and Beth Shan. Their roles included providing logistical support for the empire, provisioning troops and 


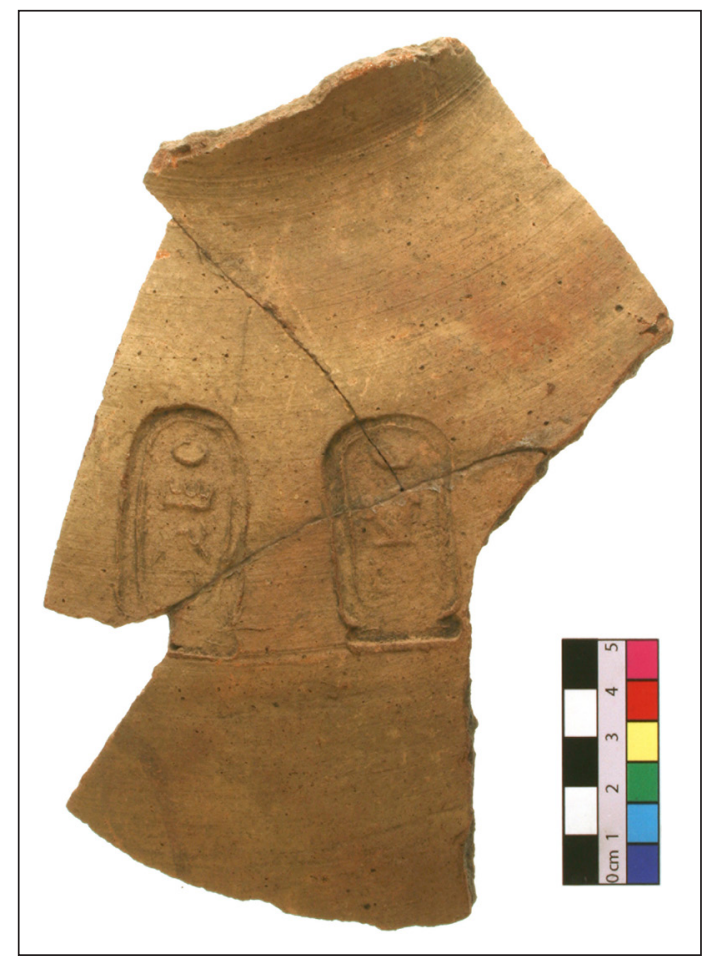

Figure 3: Ceramic storage jar with impressed stamps bearing cartouches containing the names of Tuthmes III and Hatshepsut in Egyptian hieroglyphic. UCL Institute of Archaeology Collections EXIII.112e/21.

other Egyptians stationed there or moving through on official business, controlling local security, and organising local corvée labour from Canaanite settlements. Managed by Egyptians, we suspect these centres made use of Egyptian hieratic to support many of these activities, although only a few texts inked onto ceramic vessels and sherds have survived. Vessels were also the primary surface material for hieratic votive and religious texts, predominantly added to the surface in ink or paint after firing. Hieroglyphs appear to be used in a wider range of settings. Stamps bearing cartouches were impressed onto storage jars before firing, from the co-regency of Hatshepsut and Tuthmes III onwards, probably to mark the property of royal estates (Higginbotham 2000: 254; Figure 3); they were carved into the surface of stone architectural elements, statuary and stele, incised into elite ivory objects such as musical clappers, pen cases and furniture inlays, or metal signet rings, and included in the glazed designs of faience vessels and votive objects, while the popularity of scarabs continued. This was a market driven by a combination of Egyptian imperial policy, increasing numbers of Egyptians working in the region, and a desire to emulate Egyptian visual styles amongst Canaanite elites. The sum total of these varied spheres of use would have been that Egyptian writing was much more visible to the local population than ever before.

In addition to these developments, the alphabetic Proto-Canaanite script continued to be used sporadically amongst local elites, most probably recording a local West Semitic language, although the shortness of most inscriptions makes clear identification difficult. It is applied to a range of personal items, including a gold signet ring, and ceramic bowls, jugs, a lidded pyxis and spouted cup (Hamilton 2010; Sass 1988: 101, figs 143-147, 156-160, 163-167, 178-184, 268-270; Figure 4). Inscriptions were painted or incised both before and after firing with all this implies for the agency behind the text. The signs are often cursive in character using either technique, but 


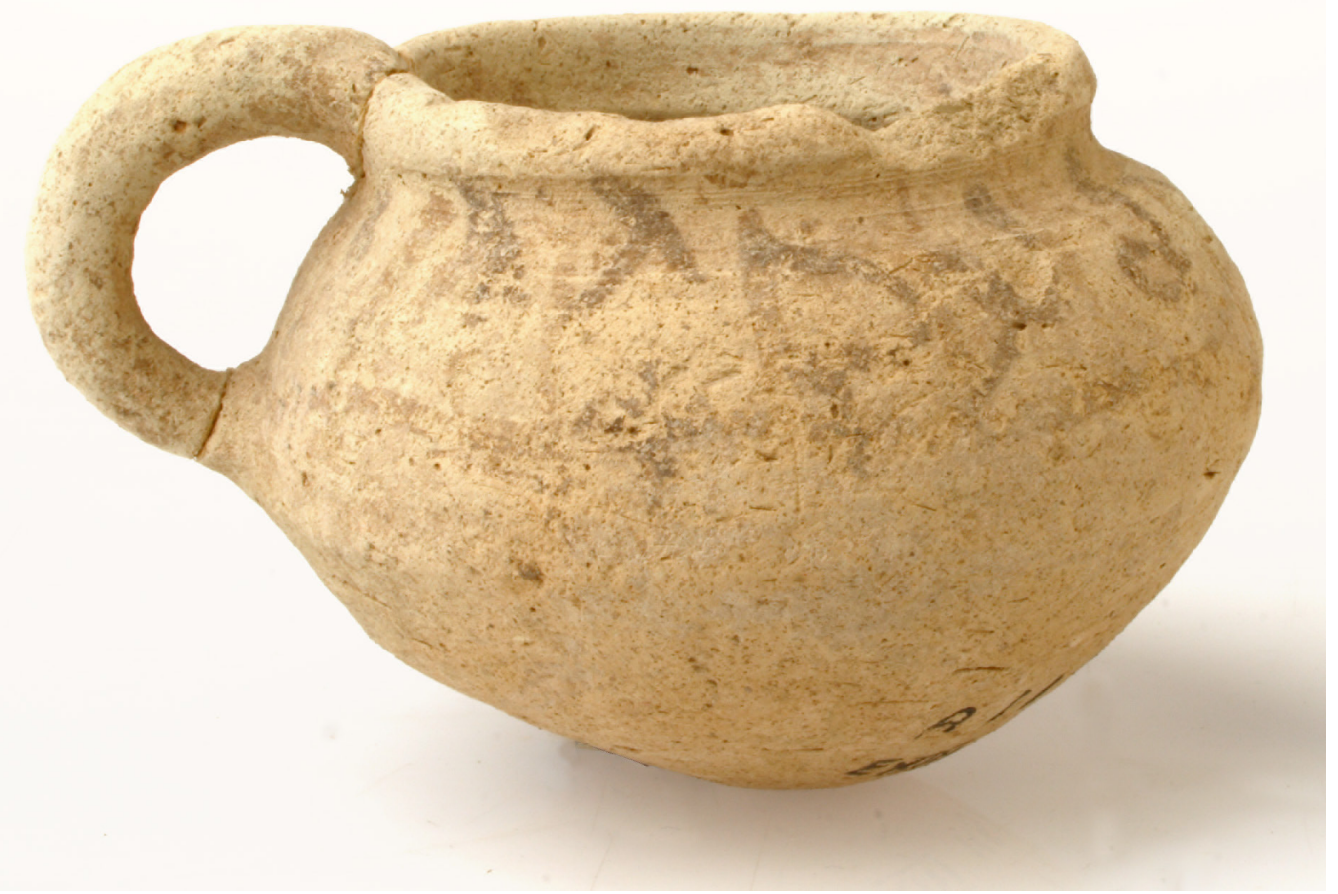

Figure 4: Ceramic spouted cup (spout now missing) from Tell el-Ajjul Tomb 1109, with painted Proto-Canaanite ownership inscription reading: 'this (belongs) to Yrș', (the) Can[aan]ite' (Hamilton 2010: 107). UCL Institute of Archaeology Collections EXIII.115/1.

occasionally when incised are rendered in a more linear fashion. They appear in tombs, temples and as domestic refuse, pointing to a wide range of contextual settings. Tablets written in ProtoCanaanite have not been found. This script appears to have been used in a less formal and managed way than either cuneiform, Egyptian hieroglyphic or hieratic.

Additional foreign scripts make a sporadic appearance. A clay bulla with an impressed royal Hittite seal was found at Aphek, where it had been discarded in a building thought to be used by a local administrator (Goren et al. 2006); the remaining Hittite texts are inscribed into either metal or stone and served as personal seals and signet rings (see below), perhaps representing sporadic diplomatic activity. Finally, there is a limestone bowl with a capacity inscription cut into the exterior upper walls in a script that is possibly Linear A (Finkelberg et al. 2004).

The following discussion will attempt to review the evidence for Bronze Age writing, in all its material forms, according to the role it may have played within local communities. This involves dividing the evidence into a number of categories: uses for administration and information management, communication, education, diplomacy and politics, to support religious beliefs (funerary, votive and protective) and to mark ownership. These categories are a useful tool, although it should be noted that official and private uses may have sometimes overlapped and at times be difficult to categorise. This study has been deliberately limited to the distribution of texts in the Southern Levant (modern Israel, Palestinian Authority and Jordan), as quite different circumstances may have been operating on cities further north, such as Byblos, with its particular links to Egypt, or Ugarit, a trading entrepôt with an unusually cosmopolitan nature due to its physical location on the interface between the Near Eastern and Mediterranean spheres. Core data used in charts and tables has been drawn from material that can be dated to the Middle and Late Bronze 


\begin{tabular}{|l|l|}
\hline Middle Bronze I & $2000-1750$ вС \\
\hline Middle Bronze II & $1750-1650$ вС \\
\hline Middle Bronze III & $1650-1550$ вС \\
\hline Late Bronze I & $1550-1400$ вС \\
\hline Late Bronze II & $1400-1150$ вС \\
\hline Iron Age & $1150-520$ вС \\
\hline
\end{tabular}

Table 1: Chronological chart of the Southern Levant.

Ages only. It excludes material whose identification or chronology is uncertain, and texts comprising a single sign, which may have functioned as identification marks or symbols rather than writing. Scarabs and scaraboids were also excluded from statistical comparisons, as the data set was too large to be included; a smaller case study of some aspects of this material has however been incorporated. A chronological chart of the periods covered by this chapter may be found in Table 1, and a map showing sites under discussion in Figure 5.

\section{Administrative Uses of Writing}

Writing was needed to support local Canaanite government and the later imposed superstructure of Egyptian government. Both would have similar requirements, including account keeping to manage personnel and supplies, to maintain and legitimate communications and record legal matters. It seems likely that the language and script used to record these activities would have differed depending on the authority behind them.

Surviving texts suggest that Akkadian cuneiform was the writing used to manage local government, with 13 tablets recording lists of goods or personnel, 19 letters, and three legal texts ranging across Middle and Late Bronze Age contexts (Horowitz et al. 2006). Only a single administrative text has been found that utilises West Semitic language and alphabetic cuneiform script: a legal tablet from Taanach, dating to the early $12^{\text {th }}$ century BC. The execution of the text is unusual on a number of grounds, including the way the letters are shaped, the direction the text is to be read, and the lack of word dividers, which may reflect a weakening of scribal tradition and the appearance of a less professional class of scribe at this time (Horowitz et al. 2006: Taanach 15). This rare example aside, what is noticeable in this assemblage is the standardisation in the way 'official' texts are being rendered, with no variation in material use or object form that we can see. Official writing is very much tied to the stylus and tablet paradigm, limiting the physical contexts of its use.

In Egypt itself hieratic is the traditional script used for administrative purposes, and this practice appears to have been imported to the Southern Levant during Egypt's Late Bronze Age occupation of the region. However, remarkably few physical examples of these sorts of texts have survived, making us suspect that records were often made on perishable materials, such as papyrus or wooden writing boards, also mirroring scribal practice back in Egypt, which have left little trace in the archaeological record bar the occasional imprint on the back of clay bullae (e.g. Dothan 2008: 65; Mumford 1998: 1614 and n. 390). There are, however, hints at more casual uses of writing. A broken sherd at Tell Sera' was used as a surface for a legal text, added in ink (Goldwasser 1984: pl. 7.2), and another inscription was inked onto the shoulder of a storage jar at the Egyptian garrison site of Beth Shan as a form of quality control (Wimmer 2007: 688-689, pl. 77.2). These examples hint at a greater flexibility in how this technology was applied. 


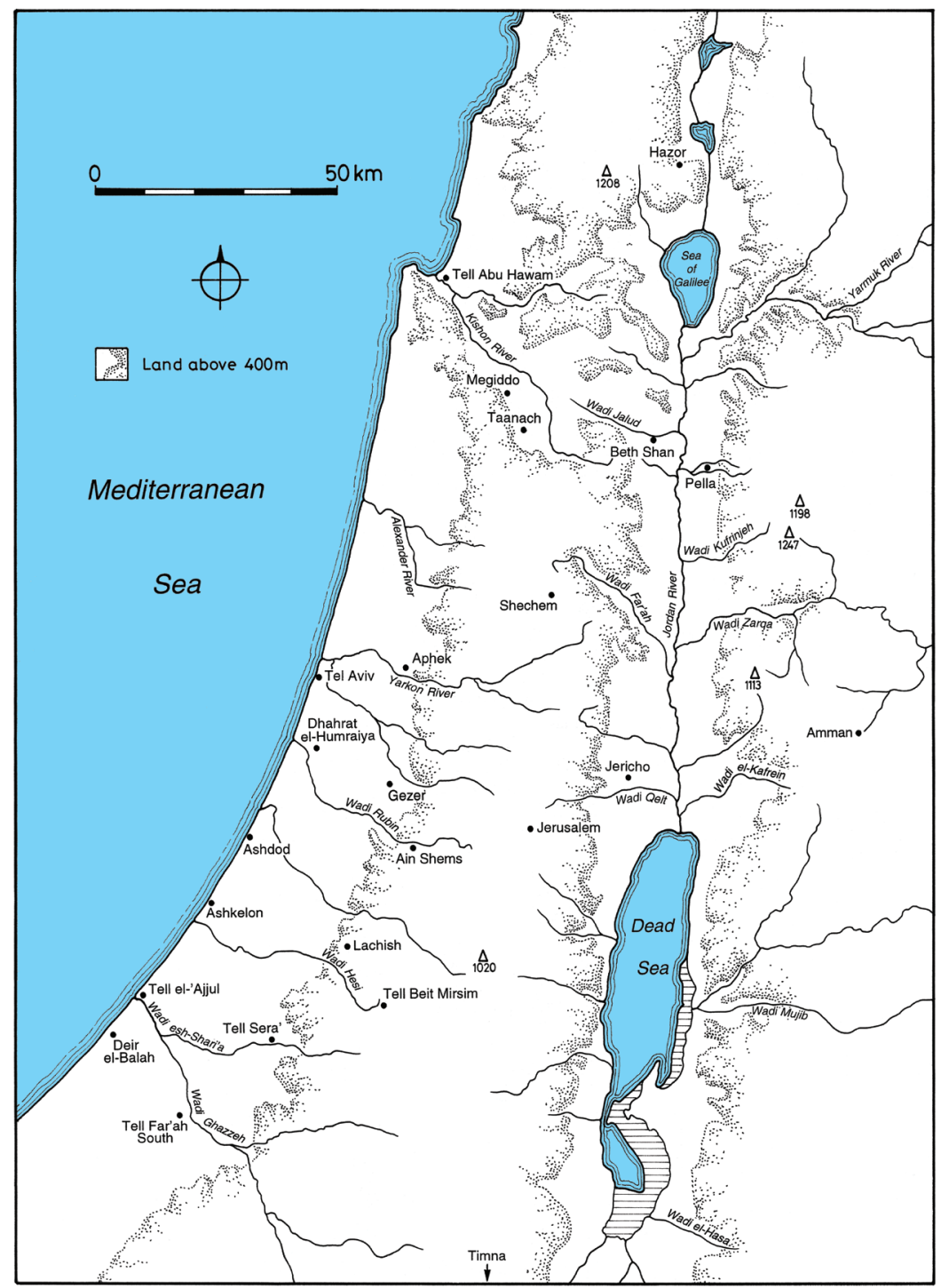

Figure 5: Map of sites discussed in the text.

Travellers between Egypt and the Levant were often used as couriers for official correspondence, as described on the recto of Papyrus Anastasi III, where letters are seen passing through a border post en-route to Egyptian officials and the Prince of Tyre (Higginbotham 2000: 48-49). It would appear that writing was used not only to give a message of authority and provide future accountability, but also to identify and legitimate the couriers themselves. Textual references point to the use of 'passports': government documents granting the bearer permission to travel through Egyptian territory without hindrance or charge, and offering proof of the official nature of their activities. Such a document, described as 'rescripts from Amon-Re', is referred to in the Report of Wenamun, an Egyptian literary text describing a journey into the Levant and thought to have been composed in the $21^{\text {st }}$ dynasty; however, the physical appearance of this authorisation is never specified (Simpson 2003: 117). 
One can nevertheless hypothesise that letters of passage would need to be both portable and secure against unauthorised tampering. While lightweight, papyrus must be rolled up and sealed with a clay bulla to secure its contents, which can only be read on breaking the seal. This would be of little use if the passport had to be shown on multiple occasions. A better solution would be to use a clay tablet, as once impressed with an official seal and then baked, its contents remain fixed. A few actual examples of these passports have survived, and they do indeed take the form of clay tablets. They were found in the Tell el-Amarna archives, dating to the later part of the $18^{\text {th }}$ dynasty. One such is EA 30, a small sub-rectangular tablet, only $6 \mathrm{~cm} \times 4.8 \mathrm{~cm}$ in size and so easily held in one hand, with its Akkadian text impressed on one side and running over to the top of the reverse where it was impressed with a cylinder seal (Moran 1992: 100; British Museum 1988.10-13.64). The contents of this tablet tell us that it accompanied a messenger sent by the King of the Mitanni, in Syria, to the Egyptian court.

A more 'unofficial' mode of communication may be represented by a unique clay cylinder seal from Beth Shan, inscribed with a letter addressed to the Canaanite ruler Lab'aya and written in Akkadian cuneiform. It has been suggested that this may represent a deliberate attempt at secrecy, by choosing a shape that could masquerade as a personal seal; both the sender and recipient were known to have been involved in anti-Egyptian activities (Horowitz 1997: 99).

\section{Writing and Education}

The earliest traces of writing being used as an educational tool come from Middle Bronze Age Hazor, where a clay prism was found bearing cuneiform multiplication tables (Horowitz et al. 2006: 78-80, Hazor 9). Another specific form of text is represented by two clay liver models with cuneiform inscriptions instructing the student on how to 'read' and interpret this type of object (Horowitz et al. 2006: 66-68, Hazor 2-3; Figure 6). These models represent a unique learning tool in many ways, as they combine written instructions with a visual template, applying the text to physical three-dimensional space. The meaning is made clear by the positioning of the text over the appropriate feature of the liver, not by any description within the text itself. This distinctive approach can be linked to the purpose of the text, which is not an exercise in developing writing technique or learning vocabulary, but in the art of divination.

From the Late Bronze Age come a handful of lexical tablets. These include two prisms found at Aphek; these are made out of local clay and provide lists of terms in Sumerian, Akkadian, and a West Semitic language (Goren et al. 2006: 162-164; Horowitz et al. 2006: 29-32, Aphek 1 and 3). Similar lists are known from tablets at Ashkelon and Hazor (Horowitz et al. 2006: 42-43, Ashkelon 1, 73-74, Hazor 6). Analysis has shown that many of these tablets were made out of locally sourced clay, pointing to local scribal activity (Goren et al. 2004; 2006). This is supported by idiosyncratic usages of Akkadian that suggest scribes were trained regionally and independently of other writing traditions (Gianto 1999: 127).

What makes these objects physically suited to educational purposes? Both prisms and tablets were designed to offer multiple surfaces for writing, with the scribe manually turning the object over as each surface was complete. The experience would be similar for those reading the text, aided by the comparatively small size and lightweight character of the objects themselves. The small size and density of cuneiform signs meant that reading, in particular, had to allow for flexibility in handling - moving the object itself to take advantage of light and shadow, and differing personal focal lengths. 


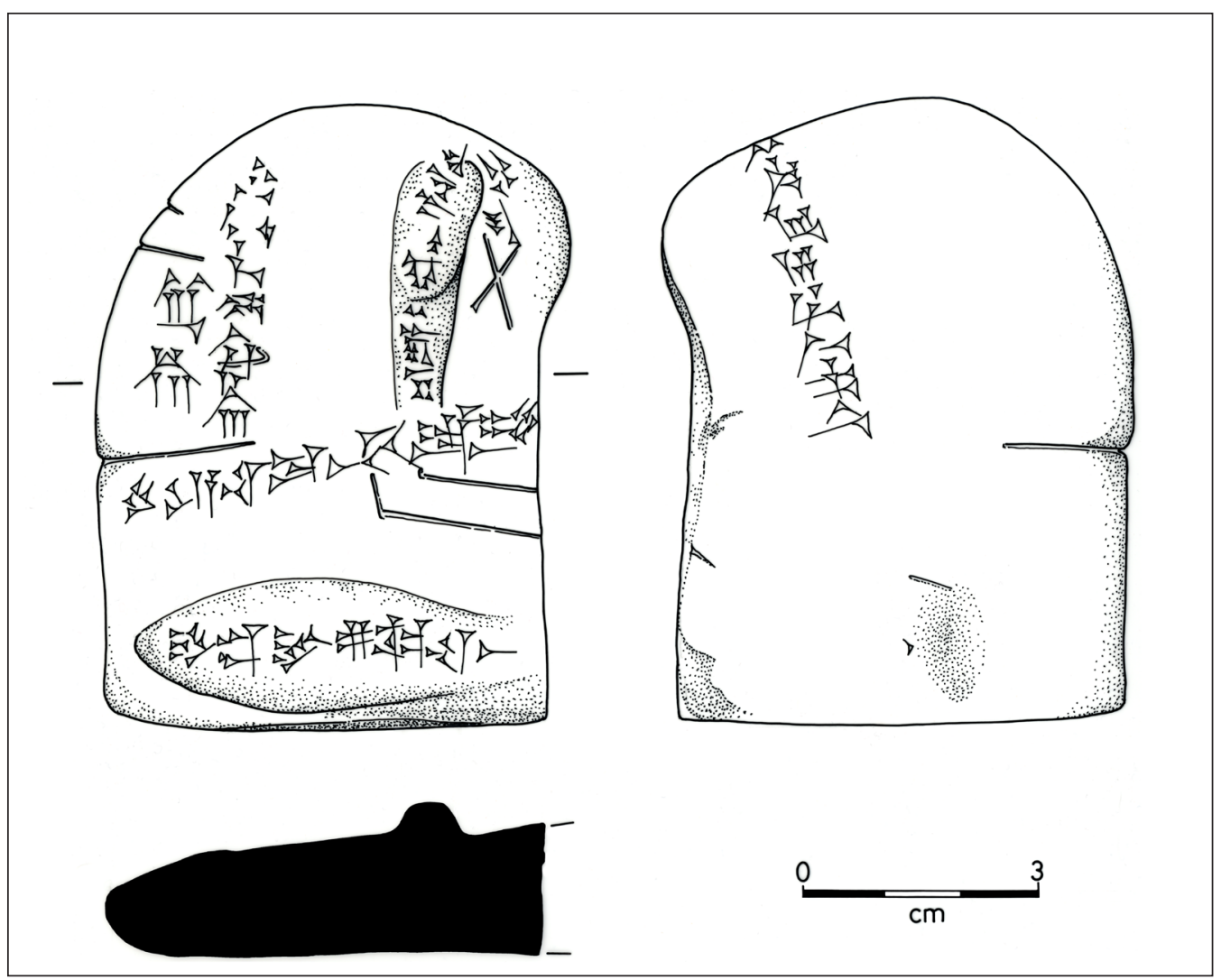

Figure 6: Clay liver model fragment from Hazor with impressed cuneiform inscription (after Landsberger and Tadmor 1964, and Horowitz et al. 2006: 209).

\section{Writing as Propaganda}

Bronze Age writing was still a restricted technology, usually associated with power and authority. It is not surprising then that it also had political applications. Stelae commemorating Egyptian victories and marking the extent of political control would have been a public statement of both achievement and intent; a similar effect would have been achieved through the erection of royal statuary. Examples of both these phenomena have appeared at a handful of locations in the southern Levant, most notably at Beth Shan, Tell el-Oreimeh, Ashdod, at-Turra and Tell es-Shihab (James and McGovern 1993: 249-250; Schulman 1993; Weinstein 1981: 20). Both classes of object most frequently appear in basalt, a challenging material with a Mohs hardness of six, that could be locally sourced in flows running from Eastern Galilee into the Hauran (Sparks 2007: fig. 59). At Beth Shan, this material was common not only for monumental texts but also for uninscribed vessels and tools, prompting the suggestion that the town housed its own basalt workshops (Sparks 2007: 164). However the style of carving and the use of linguistically acceptable texts points to the Levantine monuments being produced by craftspeople who were fully trained within the Egyptian system. Their choice of this material over other locally available and softer stones such as limestone may therefore have been more than a matter of accessibility; it may also have held cultural and ideological overtones. Basalt has a hardness comparable to that of granite, a material more often used for royal statuary and stelae in Egypt itself. This may have made it an acceptable substitute, containing similar potential to impress, a potential also achieved through the use of monumental 
scale. Its durability may also have been a metaphor for the durability of pharaonic control in the region. Such monuments were intended to last (cf. Piquette, this volume).

In both cases, the strongly Egyptian style of execution would make their ideological meaning readily identifiable even to the non-literate. It seems likely that this sort of monument would have been erected in visible, public places, such as marketplaces, near gateways and in temple precincts. It is also likely that they would be subject to processes of curation and be kept in the public eye for extensive periods of time. This has an obvious impact on the archaeology of this type of artefact, as many such texts will be found in deposits that date well beyond their original period of manufacture, making assessment of the way they were originally presented problematic. This appears to have been the case for stelae of Sety I and Ramses II, presumably erected during the reigns of their respective pharaohs, but recovered from a much later deposit in Beth Shan Lower Level V where they appear to have been erected on plinths in an area west of the northern temple (James 1966: 34-38). Over time, however, the value of such monuments was reduced as the rulers and officials that commissioned them ceased to be important, often leading to damage and reuse in far less prestigious surroundings (e.g. as door sills and sockets, Albright 1952: 24; Albright and Rowe 1928: 281).

Another potentially political use of writing was to mark presentation objects and diplomatic gifts. Gift exchange was an important part of creating and maintaining power relationships between elites across the Near East, as reflected in the Amarna letters and other correspondence between royal courts. While these letters do not actually tell us about whether gifted objects were inscribed, numerous high quality, prestige items bearing writing have been found that could reflect this type of event. The use of Egyptian royal names on luxury stone vessels may have been one example of this phenomenon (Sparks 2003), and a limited distribution of this type of artefact to strategically important cities and centres of power would support the idea that they were being directed at allies and courts where the Egyptians sought influence, rather than at controlled, vassal states. Only one stone vessel with a royal name has been found in the southern Levant, a calcite jar fragment at Gezer with the cartouche of Ramses II (Sparks 2003: fig. 3.4d). Its context, an LBII cistern, does not really explain how it came to be there, but one would suspect it began its career as a gift from the Egyptian court. Other types of objects with royal names are more common in the region, such as ivory objects including a pommel, pen case and semi-circular plaque (Feldman 2009: 180; Higginbotham 2000: 247; Macalister 1912, volume 2: figs 388, 456; Macalister 1912, volume 3: pl. 209, no. 97). Many of these are elite items that could have been presentation gifts. The contexts of others suggest they are more likely to have been votive offerings, perhaps being made on behalf of the king or invoking the royal cult (e.g. Figure 7a; Franken 1992: figs 3-9.5, pl. 4b; Rothenberg 1988: Egyptian catalogue nos 19, 26-28, 30, 41-47, 50, 83a, 96, 102-103, 180, 193, 195, 222).

The distribution of the special class of commemorative scarab issued throughout the reign of Amenhotep III could be considered another expression of textual name-dropping, although here we may see the recipients being Egyptians in positions of power both at home and abroad, as well as foreign elites. Examples have been found at Beth Shan, Beth Shemesh, Gezer, Lachish, Jaffa, and Qlaet Twal in Jordan (see Figure 7b; Blankenberg-Van Delden 1969). Unlike commemorative stelae or statuary, these were intensely personal objects, carved from steatite in the form of a scarab beetle, with a detailed inscription on the underside of the base recording in several registers a number of significant events in the pharaoh's reign. They could be held in the hand, but unlike other types of scarab, are significantly larger and almost cover the palm. They are both weightier, and more impressive. To a Levantine audience familiar only with small ring-mounted scarab amulets, the difference would have been remarkable. These were also objects to be possessed, rather than just displayed, as the dense text becomes visible only once the user has picked the object up.

Commemorative scarabs also stand out on a stylistic level. Scarab texts found in the region often feature strong visual symmetry, with flanking pairs of signs framing important elements 


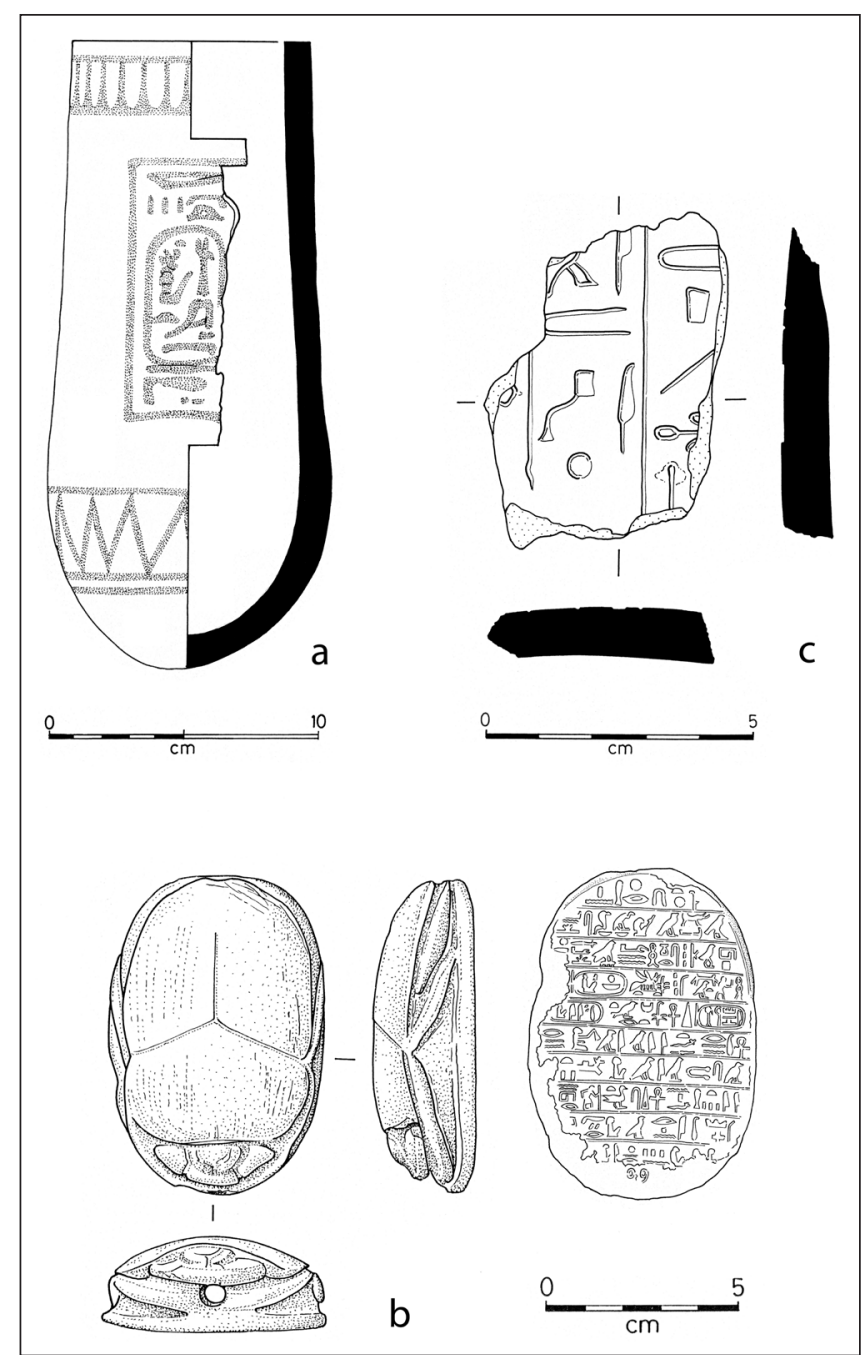

Figure 7: Objects with Egyptian hieroglyphic inscriptions. a) Faience vessel with cartouches of Tausret from Deir 'Alla (after Franken 1992: figs 3-9.5); b) Commemorative scarab of Amenhotep III from Beth Shan (after Goldwasser 2002: 192); c) Calcite canopic jar fragment from Tell el-'Ajjul. UCL Institute of Archaeology EXIII.117/1.

such as cartouches, or using hieroglyphs as filler motifs to frame figurative designs. In the case of the commemorative scarab, the surface area of the flat base is much greater, and consequently less constrained by the oval form of the object. The result is a much more formal and traditional layout for the texts, which are neatly arranged in a series of horizontal registers. The execution is also more careful and precise than usually seen. Both these features add to the prestige of the object, and underline its source in an Egyptian royal workshop.

The comparative scarcity of commemorative scarabs would also have increased their desirability. It is hardly surprising then that some commemorative scarabs seem to have been retained as heirlooms and curated for as much as several hundred years (Goldwasser 2002: 191; Jeffreys 2003: 206-207; Sweeney 2003: 58). These scarabs have been seen as a way of issuing royal bulletins, and reminding foreign rulers of Egyptian power and influence (Goldwasser 2002: 193; Sweeney 2003: 58). In each case, the text is an important element in the function and meaning of the object; while 
an Egyptian official might be expected to be able to understand the text, one might assume that the delivery of the gift to a Levantine ruler was accompanied by a formal 'reading'. After the event, the distinctive Egyptian character of the hieroglyphs and shape, magnified tenfold as appropriate for a royal recipient, would serve as a visual reminder of the purpose of the gift, whether or not the owner could revisit its specific contents. It seems likely that what was ultimately remembered generations later was the formal relationship represented by the gift, rather than the more transitory bulletin inscribed on its base.

\section{Funerary Writing}

Egypt was home to a well developed industry that provided funerary goods on which writing was an important part of the function of the object, including the Book of the Dead, heart scarabs, shabtis and funerary stelae. Access to script for funerary purposes was desirable, but nonetheless dependent on economic circumstances and so while inscriptions are common in wealthy burials, the poor often had to go without. In contrast, writing does not appear to be a usual part of funerary customs in the Southern Levant, irrespective of status. When inscribed goods do appear in burials, they appear as oddities, rather than the norm, and are usually on objects that were also used in life such as amuletic scarabs, finger rings, daggers and vessels, rather than being specifically funerary in character (e.g. Magrill et al. 2004: fig. 24.12; Sass 1988: figs 140-141, 166-167, 268-279).

The exception to this rule may occur where we see Egyptians being buried in the region, as it might be expected that Egyptians living abroad would bring with them their own attitudes to what was suitable as provision for death. In such cases, even though there may be a cultural predisposition to certain funerary texts and services, the ability of the family of the deceased to provide these may not be entirely dependent on wealth. Funerary goods, including suitable texts, are a by-product of support industries. In Egypt, these industries were well developed and there was probably a great deal of competition between suppliers to keep prices at an acceptable level. In the Southern Levant, only certain goods and services may have been locally available, and in particular, the services of suitably trained scribes may have been difficult to obtain. If scribes were in limited supply, and those that were available were chiefly employed by the Egyptian administration, private commissions may have been both expensive and difficult to secure. This may have been equally true of some of the necessary raw materials, such as papyrus. The consequence may have been that only the most wealthy of Egyptians working abroad would have been able to obtain suitable funerary inscriptions for their families, unless they had already arranged for the necessary items to be brought over from Egypt.

It is therefore not surprising that Egyptian funerary texts are extremely scarce in the Southern Levant. An exceptional example is a coffin from Tomb 570 at Lachish. This was crudely painted with a scene depicting the Egyptian goddesses Isis and Nephthys and a hieroglyphic inscription from the Book of the Dead, which it has been argued was executed by a poorly trained scribe (Tufnell 1958: 132). Higginbotham has suggested that this coffin was created by someone not conversant with the proper forms, in imitation of Egyptian funerary practice (Higginbotham 2000: 244). However there is little enough evidence that Egyptian funerary texts were available in the region to serve as the inspiration for this sort of imitation. A more likely explanation is that it was executed by an Egyptian scribe who was not used to this type of commission but was nonetheless aware of the source text.

Another class of funerary text known from the region appears on stone stelae. One example was found reused in the lining of an Egyptian pit burial at Deir el-Balah, but was thought to have originally been set up as a marker over a more expensive grave (Dothan 2008: 155; Mumford 1998: 1663, 1657; Ventura 1987: 105, 115). Ventura (1987: 113-114) has suggested that such 
markers may have been a substitute for Egyptian cult chapels and the focus of ritual activity. The fact that the lower portion of the object was left undecorated supports the idea that it was designed to be set into the ground in this way, while the choice of stone is entirely appropriate for something that was intended to have continued effectiveness over and beyond the mere event of the burial. Three similar stelae, now in the Israel Museum, have no reliable provenance but are thought to have been looted from the same site (Ventura 1987). All these texts refer to Osiris and give the name of the deceased. Other stelae with Egyptian funerary inscriptions have been discovered in Jerusalem (Barkay 1996: figs 5-6), and Hazor (Goldwasser 1989: 344-345); an uninscribed fragment from a funerary stele has also been found at Beth Shan (Ward 1966: C4, 171). The majority of these stelae were probably made from local materials, suggesting a measure of expediency, but in at least one case the stone was said to be imported Nubian sandstone (Goldwasser 1989: 344).

A well executed funerary inscription was also discovered in the 1500 house at Beth Shan, comprising fragments of a stone lintel for The Commander of Troops, Ramses Weser-Khepesh (James 1966: fig. 93.1, 4). This was part of the structure of the building, which was decorated with a number of inscriptions on door posts and lintels, and is thought to have been the residence of the highest ranking Egyptian at the site. Funerary inscriptions of this type are said to have been placed in private houses at a number of sites in Egypt (Ward 1966: 161, 168) and so reflect a space for the living with commemorative aspects, rather than a space for the dead. This sort of architecture would have made a substantial impression on the non-Egyptian residents of the site, whose own dwellings were constructed with simpler mudbrick superstructures. This elaborate stone architecture and the investment of resources it represented sent a message of power and control. The inscriptions would probably have been placed at visible points such as major entranceways to capitalise on their impact. Although comparable grandeur was present in contemporary temples and palaces at nearby sites such as Pella and Hazor, there does not appear to have been a local tradition of incorporating visible writing into the design in this way, so this feature in particular would stand out. Such buildings would also have had an impact on Egyptian personnel. The sight of Egyptian architecture decorated with Egyptian script would have provided a familiar and comforting environment for those stationed in otherwise alien surroundings.

Another object on which we might expect to see funerary texts is the Egyptian shabti, a type of mummiform figurine that became common in Egyptian funerary assemblages of the New Kingdom. The inscription on a shabti has a very specific role, as it gives the object the power to function as a substitute worker for the deceased in the afterlife, freeing them from manual labour. To this end, shabti texts were usually personalised, with the name of the owner and a formulaic spell. In some cases, a space was left blank for the name to be filled in at or after the time of purchase (Stewart 1995: 47). This seems like a very practical solution to the unpredictability of death, allowing stock to be built up which could presumably be taken and customised elsewhere if required. Despite their popularity in Egypt, and despite the fact that numerous Egyptian personnel were stationed in the Levant and presumably must have sometimes died there, only a handful of clay and faience shabtis have been found in burials across the region, at Timna, Deir el Balah, Tell el-Ajjul, Arsuf and Beth Shan, (Dothan 2008: 148; Oren 1973: figs 45.24, 47b.26-28, 49.22-24, 50.13, 76.9; Rothenberg 1988: fig. 28.2). Within this group only the single shabti found at Timna had been inscribed. How should we interpret the absence of such inscriptions? Is this simply coincidence - after all, uninscribed shabtis are sometimes found in Egyptian tombs of the period (e.g. Gurob Tomb 20; Petrie 1890: 38)? Or does this reflect either a deliberate adaptation of usual Egyptian practice, or unusual circumstances relating to local production of this type of object? Several possible scenarios can be proposed to explain this phenomenon.

- A personalised or inscribed shabti is something confined to wealthier individuals, and the kinds of people represented in the tombs discovered to date did not fall into this category. 
- It was too difficult, or expensive, to import inscribed shabtis from Egypt. Time may also have been a factor, as mummification was not practised on any of the burials found in association with shabtis in the Levant. Consequently, the body would have begun to decay before funerary equipment could be ordered and sent from Egypt.

- While the personnel servicing the funerary industries at each site included craftspeople who could make shabti bodies, they did not include support staff with scribal training who could create the necessary hieroglyphic inscriptions.

- The idea of the shabti has been accepted but the accompanying texts were deliberately dispensed with.

Each scenario has its own implications with regard to the identity and cultural affiliations of those working and being buried in the Southern Levant. Whatever the circumstances were, although they lack inscriptions the shabti forms are themselves accurately portrayed, which would argue against production by craftspeople who were unfamiliar with this type of object. Similarly there is no attempt to create a 'pseudo' inscription, which might be the case if either craftsperson or client wanted to reproduce the look of a shabti without having accurate knowledge of how it should actually appear.

Egyptian funerary equipment is also represented by rare fragments of canopic jars at Gezer and Tell el-'Ajjul (Macalister 1912, volume 3: pl. 210, no. 64; Petrie 1933: pl. 16, no. 48, pl. 17; Rockefeller Museum 35.4260). Such jars were used to contain the internal organs of the deceased, carefully removed from the body and preserved. Each jar was guarded by a particular deity, with formulaic texts invoking their protection. They are embodiments of not only Egyptian attitudes to death, but also the mechanics of preparing the body for burial, and can therefore be a strong indicator of Egyptian cultural practice. The Tell el-'Ajjul example comprised a single calcite sherd from the body of the jar, inscribed with a typical funerary formula of the New Kingdom and found in topsoil (UCL Institute of Archaeology EXIII.117/1; Stephen Quirke pers. comm. 2000; Figure 7c). The text was cut into the surface at the time of manufacture, and is an integral part of the overall design; the time and level of skill involved in hollowing the vessel out from a solid block of stone point to some investment of resources, and hence some value for the piece. It is possible that it was brought to the Levant as potential furnishing for an Egyptian-style burial; if so, it does not appear to have been used in this way as it was not found in a mortuary context. Alternatively, it may have been looted from a burial in Egypt and exported as recycled material for manufacturing beads and other small objects (Phillips 1992). In this scenario, the value of the object would lie not in the cultural meaning of the finished object, transformed by its shape and the power of script, but in the physical attractiveness and scarcity of the material from which it was made, and the fact that the thickness and only slight curvature of the vessel's walls would make it suitable for reworking for a new market.

\section{Votive Writing}

Short inscriptions can be notoriously difficult to interpret, and in cases where the archaeological context is unclear, it may not be possible to determine whether an ownership inscription was intended to add prestige to personal property or to mark a votive offering. The scarcity of certain scripts during this period might point to the latter scenario as being more plausible. This might apply to the alphabetic cuneiform inscriptions incised on a bronze knife at Nahal Tabor (Horowitz et al. 2006: Tabor 1, 152, 163-166), and clay axe head from Beth Shemesh (Horowitz et al. 2006: Beth Shemesh 1,157-160). The latter was made in a mould and then impressed with a stylus while the clay was still moist. It was found in a domestic context, and although the text is an incomplete abecedary, it is unlikely to represent a training piece. Not only does it appear on an unusual object 


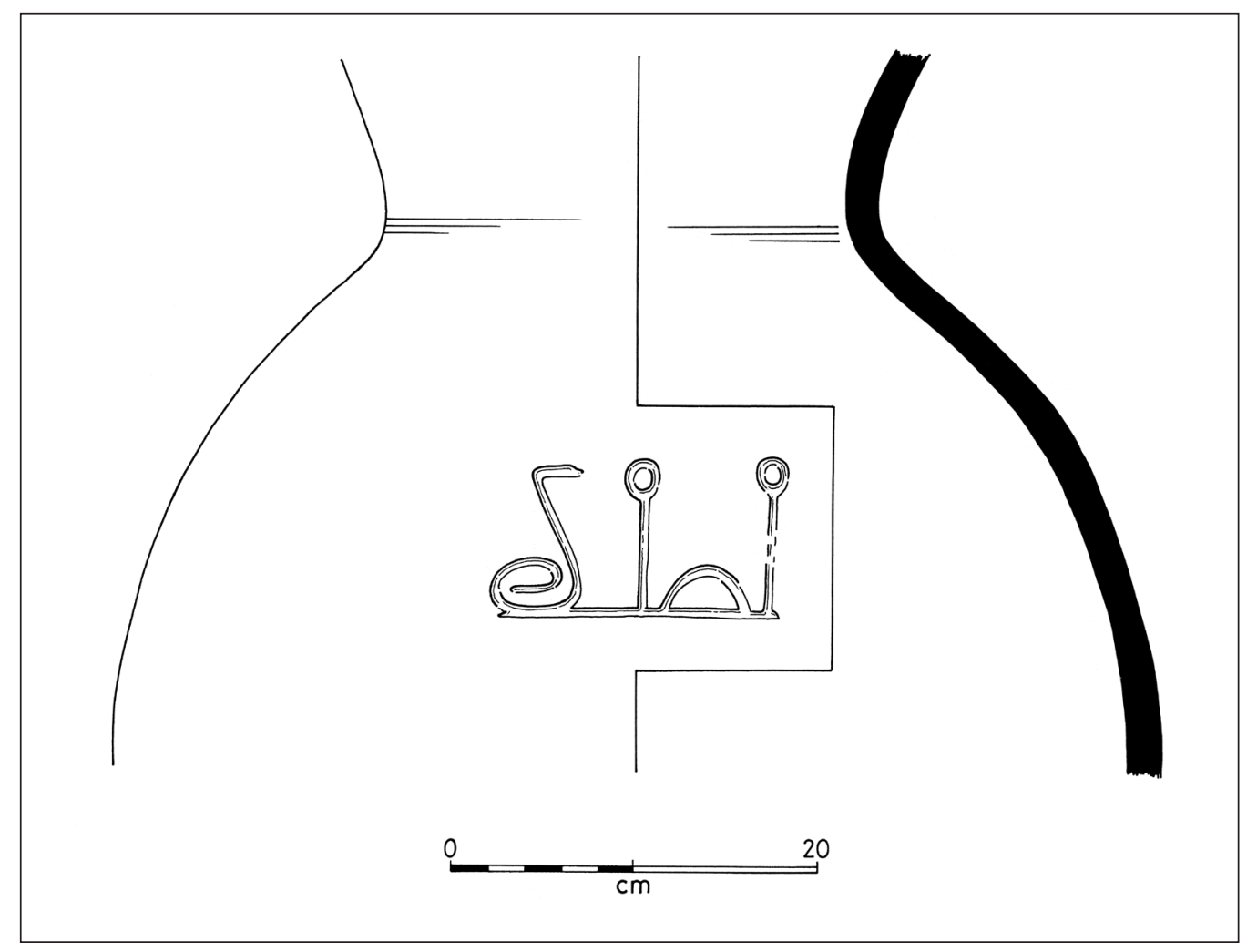

Figure 8: Jar with incised cursive hieroglyphs from Beth Shan VII (after James and McGovern 1993: fig. 11.4).

(symbolic, rather than functional, as indicated by the unusual choice of material for this form), but the text itself has to be read by rotating the object - an unhelpful characteristic if the purpose had been to educate.

A clearer use of script to mark dedications is seen on a clay model bread offering from Beth Shan level VI, stamped with the hieroglyphic phrase imny.t, or 'daily offering' (Higginbotham 2000: 225, although for an alternative interpretation, see Brandl 2009: 662-663; James 1966: fig. 105.9-10, 12). Other examples include a ceramic jar from the level VII temple at Beth Shan, bearing the word ' $k a$ ' in painted cursive hieroglyphs (Figure 8; James and McGovern 1993: 181, fig. 11.4), a jug with painted Proto-Canaanite dedicatory inscription to 'my lady Elat' found in the Fosse Temple at Lachish (Tufnell et al. 1940: 47-54), a cuneiform Akkadian dedication cut into a stone vessel from a ritual context at Hazor (Horrowitz et al. 2006: 85-86, Hazor 13), and a ceramic jug from the same site with a symbol representing the god Addu, incised before the vessel was fired, and a personal name, Isme-Addul, scratched in cuneiform into the surface afterwards (Horowitz et al. 2006: 65-66, Hazor 1). Official ritual activity may be represented by a fragmentary execration text in hieratic found on a ceramic storage jar fragment in a temple courtyard at Beth Shan, which has been interpreted as protection of the site against evil forces (Higginbotham 2000: 45-46; James and McGovern 1993: 181, fig. 15.6). This was painted onto the surface after firing.

Within this group, objects such as the clay axehead, model bread offering, and Addu and Elat jugs appear to have been made specifically as votive offerings. For some, the form is exceptional or specialised in function, while for others the nature of the inscription or decoration adds meaning to the shape. However the other objects and vessels could have been produced with other 


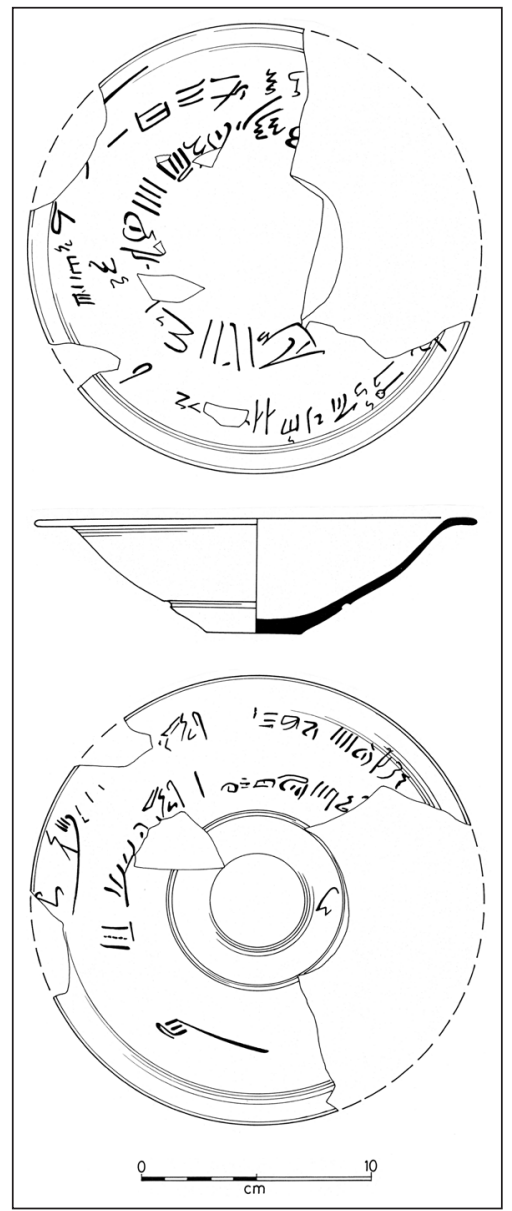

Figure 9: Bowl with painted hieratic inscription from Lachish (after Sweeney 2004: fig. 24.2).

purposes in mind, as their inscriptions were all created subsequent to manufacture of the form. It is only by the addition of the texts that they are tailored for ritual use, a potential that is realised when the actual act of dedication takes place. Their archaeological contexts show that this was achieved in the majority of cases.

An important class of object that should also be considered under this category of ritual activity is represented by a series of ceramic bowls, and possibly two jars, bearing hieratic inscriptions added after firing in ink (Figure 9; Goldwasser 1984; 1991; Goldwasser and Wimmer 1999). These inscriptions have been found at Lachish, Tel Haror, Tell Far'ah South, Tell Sera, and Deir el Balah, and initially provide something of a dilemma in terms of how the text should be interpreted. On the one hand, their content seems quite administrative in nature, recording specific dates and quantities of grain (in some cases, very large quantities); they are usually viewed in the context of produce being delivered from Canaanite vassals to Egyptian authorities as part of their tax burden. Yet it seems wrong to view the bowls themselves as a form of 'documentation' (Goldwasser and Wimmer 1999: 41) because the way in which the texts are applied to the vessels themselves is anything but administrative.

Many of our surviving examples are fragmentary, but from the more complete bowls we can see that inscriptions were placed on the exterior and sometimes on the interior as well, in one to two horizontal registers following the curvature of the walls. Opinion is divided as to whether the text 
read from inside to outside, or vice versa (Sweeney 2004: 1607), but they do appear to have been read together. Yet how easy is it to read this sort of inscription? To understand the text, you need to turn the bowl around in your hands and tilt it to different angles, to compensate for the curvature both inside and outside. On the exterior, there is the additional problem on this example of the everted rim making it hard to read the top line, unless you hold the bowl rather unnaturally. Then, if you put anything in the bowl - surely the point of a bowl? - you cannot read the interior inscriptions at all.

As an administrative record, this makes little sense, being hard to read and not remotely suited to either storage or retrieval. Wimmer's early idea that the bowls served as 'receipts' for taxation, should therefore be discounted (Wimmer 1990: 1090; cf. Higginbotham 2000: 63). Of course, as recognised by Goldwasser, while these bowls seem to record an administrative event, they represent in themselves not a bureaucratic object, but a religious one (Goldwasser 1984: 85; Goldwasser and Wimmer 1999: 41). This is because the recipient of the grain taxes they record were temple authorities, and as such the two roles overlapped. As votive objects, the text makes much more sense in relation to the object, as its aim is not to be 'read' by the living, but to give meaning to an event, and be 'read' by the gods. An ordinary bowl, by virtue of the added inscription, and being then made part of a ritual act whereby goods are being 'offered' to the temple, becomes representative of a much larger process, namely the subjugation of Canaan to Egypt and the provision of resources to Egyptian temple estates, such as the temple of Amun in PaCanaan (Higginbotham 2000: 56-59).

In Egypt, bowls are sometimes the bearers of votive inscriptions, but with some differences; there, the texts tend to relate to much smaller food offerings and the vessels themselves are often model forms (Goldwasser 1984: 85). There are however some exceptions. Occasional examples are known of hieratic letters being written on offering bowls and then being left in tombs as a way of communicating with the dead, often asking them to intervene in family problems (e.g. Petrie Museum of Egyptian Archaeology, UC 16163), while execration texts are also sometimes written on bowls before being ritually broken. The tradition of bowl inscriptions back in Egypt clearly favoured the use of hieratic. Was this choice of script for the Canaanite tax bowls a continuation of this tradition, or did it reflect some local factor, such as the circumstances under which the texts were written (perhaps reflecting a lack of time to draft formal hieroglyphs), or the types of scribes available (administrative rather than religious)?

In Canaan, uninscribed bowls appear to have a particular role as votive offerings in the temples of Lachish and may have been locally produced specifically for that purpose (Goldwasser 1984: 85; Tufnell et al. 1940: 81; a similar abundance of bowls was noticed in the governor's residence of Tell Sera', Oren 1972: 169). It may be hypothesised that the inscribed examples had a related role, but one that related more specifically to the Egyptian deities who were the recipients of these grain levies. The bowl form would be suited to a dry, rather than a liquid offering, and may well have contained a sample of the produce it represented, while the actual goods (in one case, at least 2000 sacks) would probably have bypassed the temple sanctuary and been delivered directly to one of its storerooms or warehouses (Goldwasser 1984: 80). The actual practice of combining tax inscription with offering bowl may therefore represent a hybrid response combining existing local custom, the use of votive offering bowls, with an Egyptian formula and script.

\section{Writing as Protection}

Some uses of writing are designed to be very personal, and into this class fall a number of inscribed objects that would usually be worn close to the body, including scarabs, cylinder seals, beads, pendants, and finger rings. These could serve a dual function of adornment and protection, and so were generally suited to roles both in life and death. 


\section{Scarabs and Scaraboids}

Scarabs and scaraboids were a popular personal possession in the southern Levant. A narrow perforation was bored through the centre, which allowed them to be mounted and worn in a variety of ways. They could be threaded onto a string and worn around the neck or wrist, traces of which rarely survive in the archaeological record other than by the position of the scarab on the body in tombs. Scarabs could also be mounted onto a narrow pin, which fitted into the flattened and perforated ends of a metal finger ring. The pin fitted loosely, allowing the scarab to be swivelled on its setting so it could be worn with the inscribed base flat against the skin for comfort, but rotated if the owner wished to look at the inscription or use it as a seal.

This most Egyptian of objects was adopted and then adapted by Canaanite craftspeople, who set up their own workshops during the Middle Bronze Age, perhaps under the influence of Canaanite communities in the Egyptian Delta and Byblos (Ben-Tor 1998: 162; Goldwasser 2006: 122). Their popularity quickly spread, so that by the MBIIB scarabs were considered an important part of the funerary assemblage; at Jericho, for example, they appear in nearly $70 \%$ of all Middle Bronze Age tombs. Most people now agree that their primary function in these contexts was as a protective amulet (Ben-Tor 1998: 162). A variant on the inscribed scarab is an all-in-one faience ring, a form that appears in Egypt during the early $18^{\text {th }}$ dynasty, and somewhat later in the Levant (Higginbotham 2000: 245). These typically comprise either a royal name or a religious inscription; less commonly they might feature a single amuletic sign, such as an $u$ djet, which represented the eye of Horus (e.g. James and McGovern 1993: fig. 74.1). They are therefore less diverse in design and content than contemporary scarabs, although their function is assumed to be similar. However, their design is always visible, worn openly on the hand, whereas scarabs were mounted with the inscribed surface hidden against the skin.

While some of these objects were imported directly from Egypt, and represent canonical use of writing for their form, this was not always the case with locally produced scarabs. The way in which hieroglyphic writing was adapted within Canaanite workshops suggests that the signs were not being read as texts per se, with the appearance of pseudo-hieroglyphs and errors in the shape of various signs, as well as combinations of signs that make no linguistic sense (Ben-Tor 1998: 158). However the limited repertoire that is borrowed and repeated as decorative elements, often arranged into symmetrical patterns, may point to the borrowed signs having particular significance to Canaanite markets. As a pictorial script, this sort of transference is entirely plausible (Goldwasser 2006: 121). Either way, the popularity of scarabs and scaraboids meant that many Canaanites were able to come into close personal contact with Egyptian hieroglyphs and to develop a familiarity with the general appearance of the script, without necessarily developing any literary skills. They were accessible, in a way that some votive texts, funerary stelae or lintels over the doorways of Egyptian administrative buildings may not have been.

I sampled a series of scarab assemblages from sites across the region in order to examine this phenomenon and test how important hieroglyphs were as an element in this class of object. These were chosen on the basis of the availability of comprehensive scarab data for each site, and to represent possible regional variation based on geographic location; to avoid contaminating the results, purchased scarabs and those found in post-LB contexts were excluded. This resulted in a dataset of 1205 scarabs from Tell el-Ajjul, 401 scarabs from Jericho, 71 from Pella and 430 from Lachish. The scarabs from each of these sites were analysed according to the role played by hieroglyphic signs in scarab decoration. The aim was not to distinguish between good or 'readable' inscriptions and the more decorative or symbolic uses of hieroglyphs, but to determine how important script elements were to the overall design, and hence function, of scarabs in the Southern Levant. The more prominent this element, the more visible, and hence accessible it becomes to Canaanite populations on the most personal of levels. 


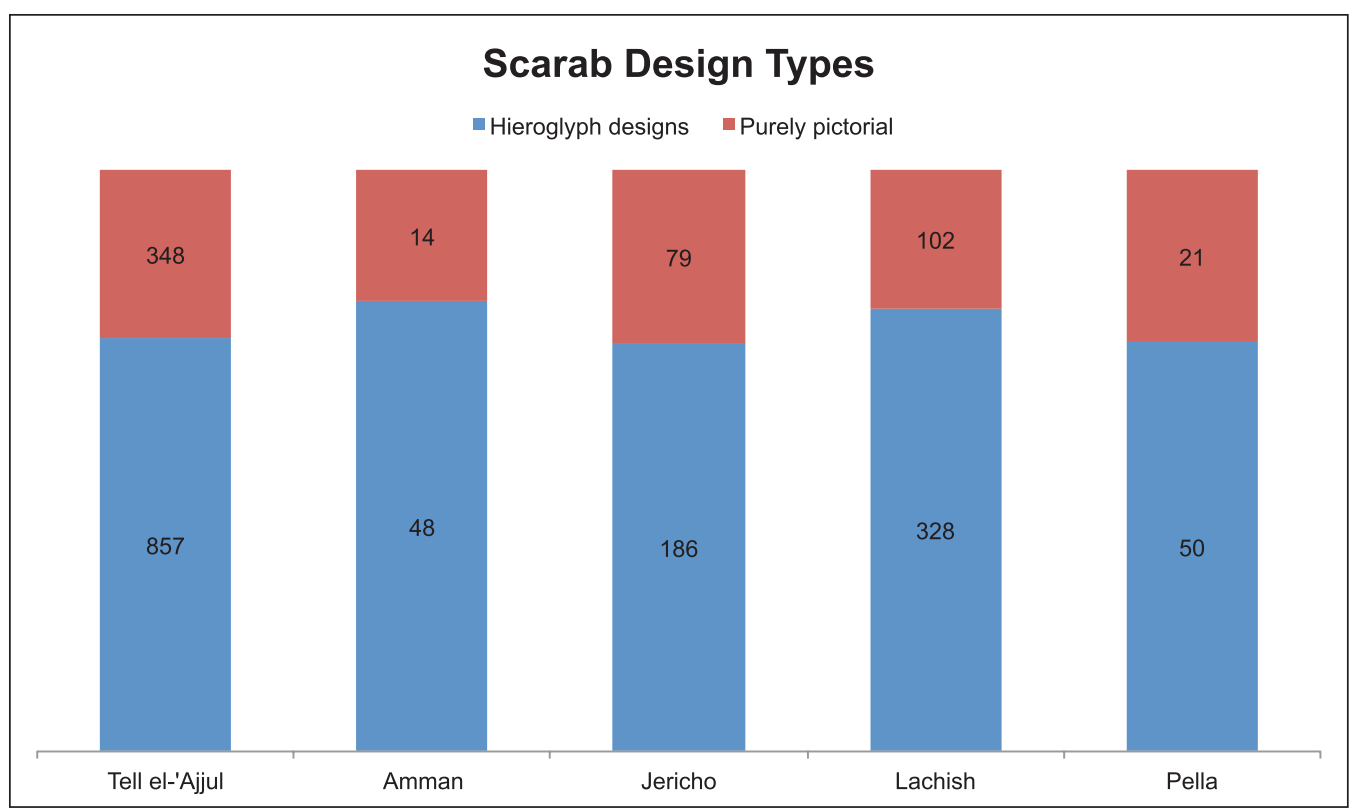

Figure 10: A comparison of scarabs with purely pictorial designs and those incorporating hieroglyphic signs from selected South Levantine sites.

The assemblage was categorised into scarabs based purely on figurative imagery (humans, deities, animals) or geometric designs (scrolls, twists, concentric circles), and those which incorporated hieroglyphs, either as the sole decoration or as filler motifs surrounding figurative or geometric scenes. This enabled a comparison of scarabs with and without script, which demonstrated an interesting phenomenon: irrespective of location, in all the sites studied script-based scarabs made up between two thirds and three quarters of the total scarab assemblage (Figure 10). This shows that to local consumers text was somehow seen as an important part of what a scarab was and how it functioned. Most Canaanites, it would seem, wanted their scarabs to have hieroglyphs. This may well relate to the idea that writing has power, and is therefore particularly suitable for objects that have protective or magical functions; in such a case, not being able to read such writing only adds to its value and mystique. The fact that the writing was Egyptian, and therefore foreign and exotic, may have only served to increase its potency; while of course by the time of the Late Bronze Age there were other associations to be made, namely with a country and culture that had become the dominant political and military power of the region.

Another class of object where we might expect to see a similar use of writing is the cylinder seal, which was frequently used as an amuletic or votive item, and which could be worn in a ring, as a necklace, or suspended from a toggle pin. However here we see that text, or elements of text, were very much the exception rather than the rule, and where they do appear, there is a stronger association with semi-precious materials such as jasper, lapis lazuli and hematite than less prestigious materials such as faience, although the latter does occur. Those that carry cuneiform inscriptions are mostly concerned with seal ownership (Horowitz et al. 2006: 39, 47, 95-97, 105-107, 149); however the rare examples with Egyptian script are more eclectic. An example from Tell Far'ah South offers a combination of signs more usually seen on the Canaanite anra scarab series, socalled after its use of a particular subset of hieroglyphs, and which presumably carried the same local significance, although they do not make any sense as an Egyptian text (Parker 1949: 10, no. 17; Richards 2001: 11-12). Another seal from Jericho is more of a cultural mix, incorporating 
two ankhs into an otherwise very Near Eastern scene (Teissier 1996: 115, cat. 242), and one from Tell Beit Mirsim goes so far as to use both hieroglyphs and what may be stylised cuneiform signs together (Teissier 1996: 110, cat. 226).

\section{Amulets}

The Late Bronze II period sees the introduction of a small group of amuletic pendants, the shape of which are based on individual Egyptian hieroglyphs (Figure 11). These made up some 14\% of McGovern's corpus of pendant types for the region (to which can be added James and McGovern 1993: fig. 75.5, making 117 examples), and eight basic types appear to be represented - corresponding to the ankh, djed, heh, tit, udjet, hst, ib, and nefer signs (McGovern 1985: class V, 58). Many of these signs are also common to the local scarab series - with the ankh, djed, udjet, and nefer being especially popular. Like the scarabs these are very personal objects that would probably have been accessible to people outside the official administration. A number of these amulets are prescribed funerary types from the Egyptian Book of the Dead (e.g. Andrews 1994: tit 44, ib 72 , and djed 83), although this is not always the type of context in which they appear to have been deposited in the Levant (see Table 2).

These amulets appear to have a comparatively limited distribution, having been found at Beth Shan, Megiddo, Tell Abu Hawam, Dhahrat el-Humraiya, Lachish, and Tell el-Ajjul. There was a particular clustering of examples at Beth Shan, where they may actually represent a rather limited number of individual collar necklaces (McGovern 1985: 63, 128); there is also evidence that many of these may have originated in Egyptian-run faience workshops at the site (James and McGovern 1993: 162). Those signs with a naturally vertical orientation may have a single suspension loop at the top, and so could have been worn as pendants. Others in this class have loops at both top and

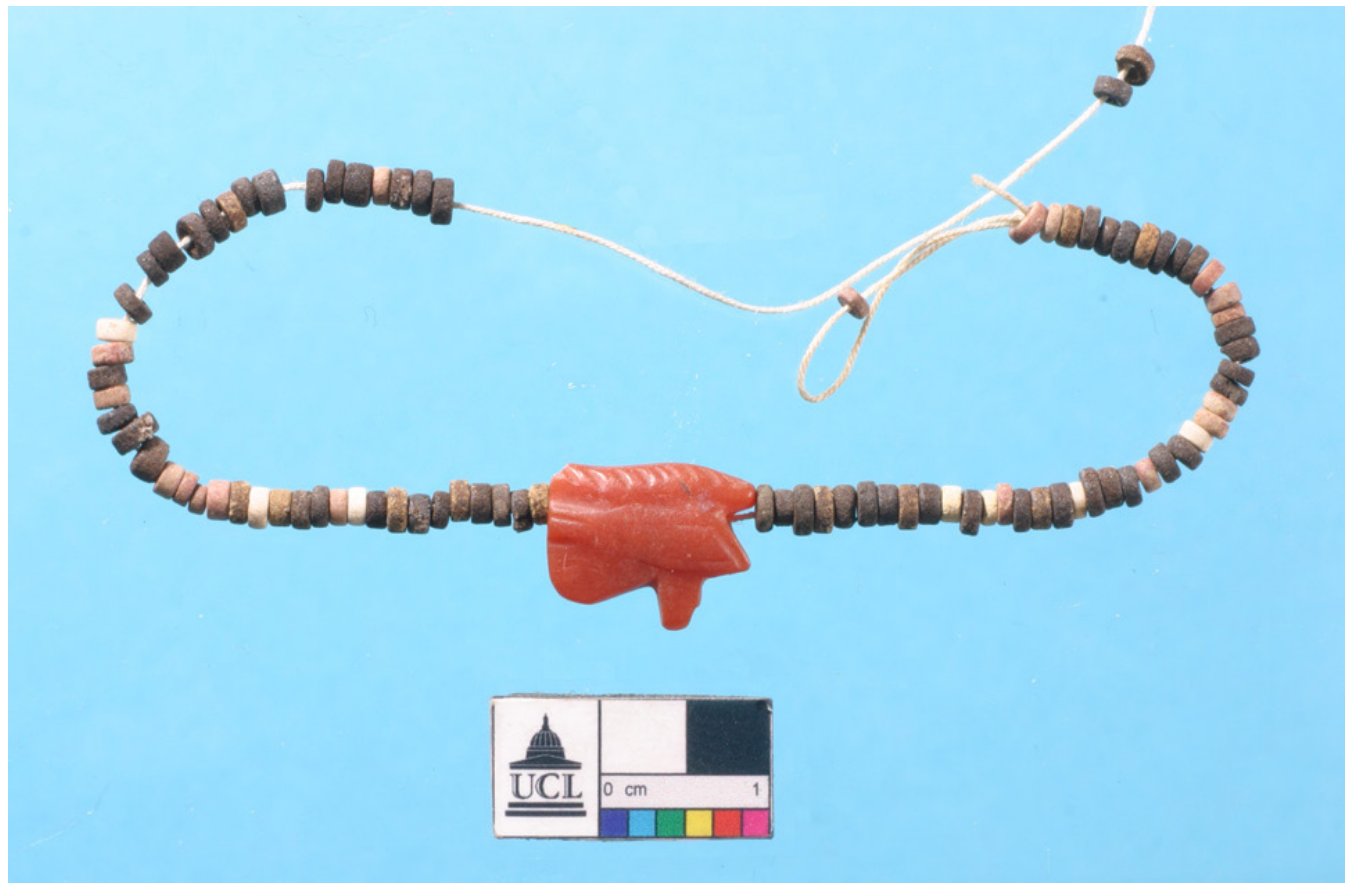

Figure 11: Faience bead necklace with carnelian udjet amulet, from Tell Fara Tomb 949, dating to the Late Bronze Age IIB. UCL Institute of Archaeology Collections EVI.23/16. 


\begin{tabular}{|l|r|r|r|r|}
\hline \multicolumn{1}{|c|}{ Amulet form } & Tomb & Temple & Other & \multicolumn{2}{|c|}{ Totals } \\
\hline Nefer & 30 & 6 & 0 & $\mathbf{3 6}$ \\
\hline Udjet & 6 & 4 & 3 & $\mathbf{1 3}$ \\
\hline Djed & 1 & 22 & 2 & $\mathbf{2 5}$ \\
\hline Hst & 0 & 12 & 0 & $\mathbf{1 2}$ \\
\hline Tit & 0 & 16 & 1 & $\mathbf{1 7}$ \\
\hline Ib & 0 & 2 & 0 & $\mathbf{2}$ \\
\hline Heh & 0 & 7 & 0 & $\mathbf{7}$ \\
\hline Ankh & 0 & 1 & 4 & $\mathbf{5}$ \\
\hline Totals & 37 & 70 & 10 & $\mathbf{1 1 7}$ \\
\hline
\end{tabular}

Table 2: The comparative frequency of Egyptian hieroglyph-shaped amulets according to context type (based on data from McGovern 1985: 125-259, and James and McGovern 1993).

bottom, and were probably strung as elements in a more complex, perhaps even multi-stranded piece of jewellery. The exception appears to be the udjet amulet, or 'Eye of Horus', which has a naturally horizontal orientation and is perforated through its length in order to maintain this. While these objects could have been used as everyday amulets by either Egyptians or Canaanites, the fact that the majority of examples are known from temple contexts has suggested that they were probably used as votive offerings or to dress cult statues (James and McGovern 1993: 128-129). It seems likely that many people using these amulets would not be able to 'read' the script these signs were taken from; yet the way the design maintains some sense of orientation shows that this was considered an aspect worth preserving. It is equally likely that there was an accepted meaning for each type, and that they were told this significance when purchasing the items. It is less clear whether the owners and depositors of these objects were Egyptian or Canaanite, and it is worth remembering that amulets in the shape of hieroglyphic signs may have been assigned a different set of meanings, depending on the cultural background of the user.

\section{Marking Ownership}

Ownership inscriptions have been briefly touched on above in relation to cylinder seals and votive offerings; the cup with Proto-Canaanite inscription in Figure 4 is an example of a text marking ownership being deposited in a funerary setting. There is, however, an additional variant found in the region, namely the personalised signet ring. These may have functioned as seals or simply as markers of identity, but are to be distinguished from the amuletic rings discussed earlier both in function and method of manufacture, being made for specific individuals, from more prestigious material, and being shaped by hand rather than being mass produced from moulds for unknown consumers. Three unusual examples have been found in the southern Levant in which the script used was Hittite hieroglyphs. The first of these is a bronze signet ring, found in a male burial at Tel Nami in association with bronze pomegranate-headed 'sceptres' and incense burners. The ring is incised with a male name, possibly $u s / s a$ and according to Singer (1993: 190) the form of both ring and name point to a Syrian owner who had adopted the use of Hittite script.

Two similar finger rings, this time in silver, were also discovered by Petrie at Tell Far'ah South (UCL Institute of Archaeology EVI.64/8-9; Singer 2003). These were inscribed with the names of 

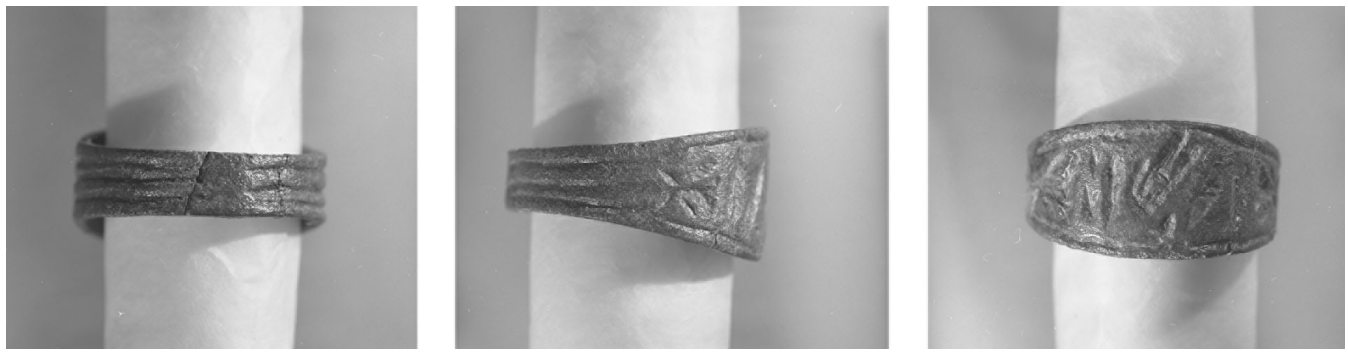

Figure 12: Silver finger ring with incised Hittite inscription, bearing the personal name Ana. UCL Institute of Archaeology Collections EVI.64/8.

their presumed owners, a man called Zazuwa and a woman called Ana (Figure 12). Both were found in the same deposit, Area EF level 386, which also contained four faience, two glass, two steatite and one limestone scarab, silver, gold and bronze earrings, faience vessel fragments and some 295 beads, pendants and amulets, made out of glass, faience, and diorite, carnelian and other stones. Many of these items have an Egyptian or Egyptianising character (MacDonald et al. 1932: pls 73.58-70, 78; most of them are now in the University College London, Institute of Archaeology Collections). The structure they came from was part of a series of rooms built near the former gateway of the site. There is nothing in the architecture or pottery of this locus to suggest that it was functioning as a cultic space, and so the most likely explanation for the deposit was that it was a domestic or commercial cache of jewellery, with the rings being included for their intrinsic or exotic value. Unfortunately Petrie did not publish any comments on the specific findspot, and it is therefore not clear if they were found in occupation debris or had been secreted away.

How did these small objects bearing the script of the Hittite empire find their way to the southern Levant? As personalised items it seems likely that their owners originally carried them there, but it is not at all certain that they still belonged to those owners when they finally entered the archaeological record. It also seems likely that the texts they bore would have been unintelligible to almost everyone in the region. The same could be said of a Hittite steatite button seal found at Megiddo (Singer 1988-1989: 106), or a hematite cylinder seal from Beth Shan which may carry Hittite hieroglyphs (James and McGovern 1993: 231, no. 2). However, like Egyptian hieroglyphs, the script used is intrinsically decorative and these objects may have been valued by non-Hittites simply for their exotic 'foreign' design; their materials may also have held appeal for their recycling value. Small, portable, personal objects such as these contrast with the more direct and official Hittite activity suggested by the Hittite royal bulla found at Aphek, which a recent study unexpectedly demonstrated to have been made from a local source of clay (Goren et al. 2006: 166-167). However ultimately these few examples only serve to underscore the fact that Hittite material culture has left very little imprint on the region, suggesting that this particular variety of crosscultural encounter was rare.

\section{Correlations of Technique, Material and Script}

In many contexts of use, there would appear to be some correlation between the properties of different materials and the way in which writing was applied to them; however craft and scribal training, cultural preference in tool use and expediency may also have been factors in the choice of writing technique (Figures 13-14). The traditional and most common application of cuneiform and alphabetic cuneiform scripts, whatever the language, was to impress it into moist clay using a stylus capable of producing wedge-shaped marks (e.g. Figure 6). As such, it had to be added during the manufacture of an object. In many cases, the object was created solely as a surface for 


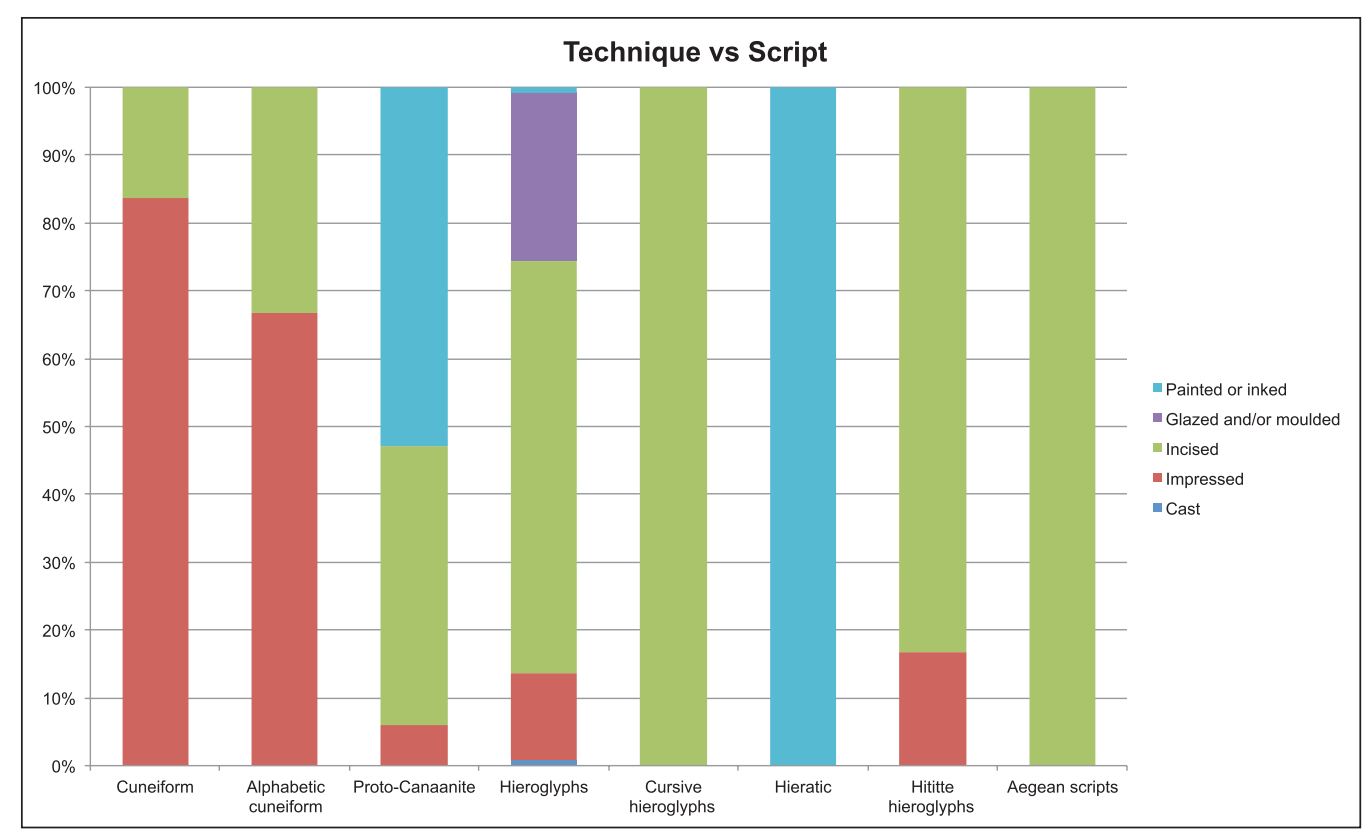

Figure 13: This chart shows the different ways in which texts can be added to objects, and how these techniques relate to script choice.

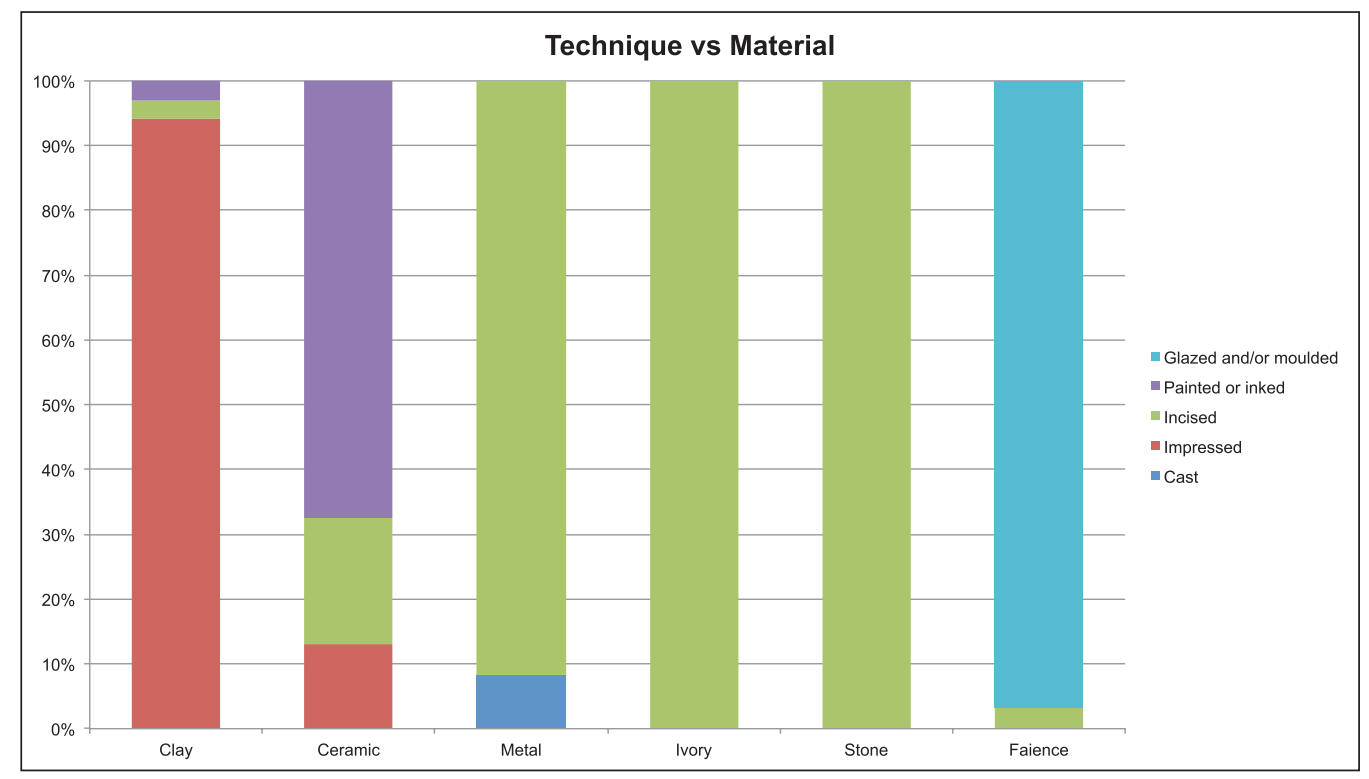

Figure 14: Writing technique can relate to the physical properties of the surface being written upon. This chart shows how technique and material relate to one another across the range of Bronze Age South Levantine texts.

the writing and so was inseparable from it. Yet cuneiform and alphabetic cuneiform were also applied to stone surfaces and to ceramics after the clay had hardened or been fired. The technique then became one of incision. In the case of cylinder seal and stone vessel inscriptions the signs 
were carefully cut to imitate the characteristic wedge-shape of the impressed version, even though different tools were in use and the material does not naturally lend itself to this kind of effect, suggesting that the script itself carried with it certain visual expectations, whatever the medium. Only occasionally is this convention ignored, as seen on a bronze knife from Nahal Tabor, where the alphabetic cuneiform signs have a more triangular head, comparable to inscriptions on metal artefacts at Ugarit (Horowitz et al. 2006: 163, n. 3; Yon 2006, 171, cat. 63). Another example is the postfiring inscription on a jug from Hazor, where the writer has abandoned the wedge-shaped letters of their Akkadian cuneiform for a simplified, linear effect (Horowitz et al. 2006: 65-66, Hazor 1).

In other scripts, the links between material, writing tool and sign form appear to be more consistent. Hieratic was a cursive script, and is predominantly applied using what is assumed to be a reed pen and ink on ceramic surfaces (Figure 9). There is a single example of a hieratic inscription being added to a ceramic vessel before firing, by dragging a pointed tool or stylus through the moist clay (Maeir et al. 2004: fig. 6). The difference may well be one of context, with the majority of texts being added by individuals outside the pottery workshop. This may in turn reflect a stronger degree of separation between craftspeople and those with scribal training. In the case of hieroglyphs, however, the two groups must have often worked closely together in the production of objects such as monumental sculpture, architectural components, scarabs and stone vessels, where the primary method of inscription was through different techniques of cutting (e.g. Figure $\mathbf{7 b}-\mathbf{c}$ ), or faience vessels, where the scribe had to work with moulds and glazes (Figure 7a). On other occasions, the texts could have been supplied to workshops ready made, as when cartouche stamps were used to impress ceramic vessels prior to firing (Figure 3). Finally, Proto-Canaanite scribes, like those using other cursive or pictorial scripts, tend to draw their signs freehand rather than applying jabbed impressions. A pointed tool is either dragged through clay before a vessel is fired, or cuts into the surface afterwards, or paint or ink is applied, most probably using a brush (Figure 4). In only one case was an inscription impressed, and then this seems to have been done using a carved stamp, similar to Egyptian practice (Sass 1988: fig. 271). The one writing technique that finds favour across all scripts in the region is that of incision, as it can be applied across a wide range of different materials and be done anywhere, using tools that need not be specific to the scribe. Its use may show the desire to modify existing objects by adding texts at a later date, and a need for flexible settings in which this may be done.

\section{Concluding Remarks}

The categories outlined in this chapter and summarised in Table 3 are designed to help explore the implications of how writing was used in the Bronze Age Levant, and should be seen as suggestive rather than definitive. In actual fact writing often functioned in more than one context, and thus an ownership inscription could be seen as a way of identifying the donor of an object when it was used as a votive offering, or an amulet that protected a person in life could be taken to the grave to extend that protection into death. Similarly inscribed artefacts can belong to multiple owners, with consequent shifts of context and meaning over the life of the object.

One striking fact about the data is how many sites have produced examples of multiple scripts in a range of materials and techniques, in some cases even when the actual sample size is very small. This appears to be a phenomenon of the Late Bronze Age, with the most cosmopolitan cities on the Canaanite map in this respect being Beth Shan and Lachish. Both shared the full range of Egyptian scripts (hieroglyphs, cursive hieroglyphs and hieratic) and the presence of cuneiform and Proto-Canaanite (while no cuneiform has been discovered at Lachish itself, this site is known to be the source of some of the Amarna correspondence, Goren et al. 2004: 289; Millard 1999: 318, fig. 2). Lachish was also the home of a rare example of an Aegean script, thought to be related to Linear A, cut into the shoulder of a vessel made of local limestone (Finkelberg et al. 2004: 1631). 


\begin{tabular}{|l|c|c|c|c|c|c|c|}
\hline & $\begin{array}{c}\text { Adminis- } \\
\text { trative }\end{array}$ & Education & $\begin{array}{c}\text { Propa- } \\
\text { ganda }\end{array}$ & Funerary & Votive & Protective & $\begin{array}{c}\text { Owner- } \\
\text { ship }\end{array}$ \\
\hline Cuneiform & $\mathrm{X}$ & $\mathrm{X}$ & & & $\mathrm{X}$ & & $\mathrm{X}$ \\
\hline $\begin{array}{l}\text { Alphabetic } \\
\text { cuneiform }\end{array}$ & $\mathrm{X}$ & & & & $\mathrm{X}$ & & $\mathrm{X}$ \\
\hline $\begin{array}{l}\text { Proto- } \\
\text { Canaanite }\end{array}$ & $?$ & & & & $\mathrm{X}$ & & $\mathrm{X}$ \\
\hline $\begin{array}{l}\text { Egyptian } \\
\text { hieroglyphs }\end{array}$ & $\mathrm{X}$ & & $\mathrm{X}$ & $\mathrm{X}$ & $\mathrm{X}$ & $\mathrm{X}$ & \\
\hline Hieratic & $\mathrm{X}$ & & & & $\mathrm{X}$ & $\mathrm{X}$ & \\
\hline $\begin{array}{l}\text { Cursive } \\
\text { hieroglyphs }\end{array}$ & & & & & $\mathrm{X}$ & & \\
\hline $\begin{array}{l}\text { Hittite } \\
\text { hieroglyphs }\end{array}$ & $\mathrm{X}$ & & & & & & $\mathrm{X}$ \\
\hline Aegean & $\mathrm{X}$ & & & & $\mathrm{X}$ & & $?$ \\
\hline
\end{tabular}

Table 3: The relationship between script and its context of use, as determined by evaluating the object type and function, alongside the content of the text itself.

Despite the diversity of scripts available at many sites, it is difficult to determine whether individual scribes were conversant in writing multiple languages. One way to demonstrate this would be through the presence of single objects with multiple scripts. Actual examples of this sort of practice are very rare. There is a clay stopper from Megiddo, stamped on its upper face with an Egyptian hieroglyphic seal (most probably a scarab), and impressed on the sides in cuneiform, giving an Egyptian personal name and a Sumerian unit of capacity (Horowitz et al. 2006: 107108, Megiddo 5). This might point to an Egyptian scribe with cuneiform training, a scenario that makes sense for a region which represents an interface between the two writing technologies. However, it should be pointed out that the hieroglyphic element of the object was produced by a seal, and so is not actual proof that the scribe in this case was able to render both hieroglyphs and cuneiform, or indeed, even read the former. Another example cited earlier was a cylinder seal with both cuneiform and hieroglyphic elements in the design (Teissier 1996: 110, cat. 226). In this case, there is even less proof of a craftsperson familiar with both languages, as the use of script as a decorative element has very different implications compared with script intended to be read, and the inaccurate rendering of many of the signs points to a lack of understanding of their meaning.

In actual fact most forms of script appear to have been used in discrete environments. Cuneiform, for example, was primarily an administrative script that was adopted for diplomatic communication, and otherwise used only within what appears to be a very small and largely closed community of professional scribes (Gianto 1999: 127). This probably explains the strong formality in the way the script tends to have been executed, irrespective of the surface material involved. Hieratic appears to have been used primarily in sites in the South Sharon plain and Negev; the bulk of examples have a votive or ritual use, with one possible legal text and an inspection marking (Goldwasser 1984: pl. 7.2; Wimmer 2007), and all appear to have functioned within the context of the Egyptian administration of the region. These sorts of texts would have been used in settings which made them inaccessible to the majority of the population, so it is not surprising that they had so little impact on Canaanite material culture and practices in general.

One possible exception to this trend may be seen with Egyptian hieroglyphs. These have the strongest visibility of all scripts, largely due to their use on a range of personal jewellery and 
amulets, and the spread of some elements of this script into contemporary decorative art. These personal uses of writing parallel the more official or governmental ones, and set the scene for transformations of meaning and use of the type that we do not see occurring elsewhere. Signs that were adopted into Canaanite repertoires in scarab and other workshops do not appear to have been transferred along with mechanisms that would allow new users to be trained in the 'correct way' of using them. Indeed, the pictorial nature of the signs left users free to assign new meanings, and use them in ways that the originators of the script had never intended (Goldwasser 2006: $126,131,134,151)$. As such, these signs lost their ability to record Egyptian speech and language. Goldwasser concludes that it was the informal context in which these signs were now being used, and this very lack of formal scribal training that paved the way for the evolution of new applications of script and the invention of the alphabet (Goldwasser 2006: 152-153). Interestingly, while the meanings of individual signs were being renegotiated, the objects on which these signs appeared did not seem to undergo the same level of transformation, and so the overall design of the scarab amulet retained strong links with its Egyptian counterparts.

The Iron I period, 1150-1000 BC, saw a gradual falling away of the visibility and use of all the scripts previously found in the Southern Levant. However it was the cuneiform and hieroglyph/ hieratic traditions that appear to have suffered the most, as the urban administrative systems that supported technical training fell into disarray and the international networks that provided much of the rationale for their use dissolved. Many major centres were abandoned or went into decline, with urban populations moving into smaller village communities, while the Egyptians eventually closed down their Levantine strongholds altogether. The Report of Wenamun, discussed earlier and thought to be set in this period, points to the continued existence of writing in Lebanon where there appears to have been stronger cultural and urban continuity at this time. But elsewhere in Canaan, archaeological evidence for the use of cuneiform, Egyptian hieroglyphs and hieratic, suggests that these scripts became increasingly irrelevant to activities within Canaan itself. In contrast, the Proto-Canaanite alphabets that had been apparently peripheral to core activities became more valued in the newly reconfigured geopolitical landscape of the Iron Age Levant. This may be because they were less formally tied to official purposes and scriptoria, traditionally being used in a more private context to mark personal property and offerings. The use of a greatly simplified sign list that was visually less complicated and more memorable than cuneiform may also have helped its spread amongst the wider community and made it less vulnerable to social and economic change. Ultimately it was this accessibility that led to transformed varieties of this writing such as Phoenician and Hebrew becoming an important tool for use by the emerging new polities in the region.

\section{Acknowledgements}

The author would like to thank Graham Reed for providing the illustrations in Figures 5-9, and the Institute of Archaeology, University College London, for permission to publish objects in Figures 3-4, 7c, 11 and 12.

\section{References}

Albright, W. F. 1952. The Smaller Beth-Shan Stele of Sethos I (1309-1290 вC). Bulletin of the American Schools of Oriental Research 125: 24-32.

Albright, W. F. and Rowe, A. 1928. A Royal Stele of the New Empire from Galilee. Journal of Egyptian Archaeology 14(3/4): 281-287.

Andrews, C. 1994. Amulets of Ancient Egypt. London: British Museum Press. 
Barkay, G. 1996. Late Bronze Age Temple in Jerusalem? Israel Exploration Journal 46(1-2): 23-43. Ben-Tor, D. 1998. The Relations Between Egypt and Palestine During the Middle Kingdom as Reflected by Contemporary Canaanite Scarabs. In Eyre, C. J. (ed.), Proceedings of the Seventh International Congress of Egyptologists. Leuven: Peeters, 147-163.

Blankenberg-Van Delden, C. 1969. The Large Commemorative Scarabs of Amenhotep III. Leiden: E. J. Brill.

Brandl, B. 2009. Scarabs, Seals, Sealings and Seal Impressions. In Panitz-Cohen, N. and Mazar, A. (eds), Excavations at Tel Beth-Shean 1989-1996, Volume 3. Jerusalem: Israel Exploration Society, 636-684.

Cross, F. M. and Stager, L. E. 2006. Cypro-Minoan Inscriptions Found in Ashkelon. Israel Exploration Journal 56(2): 129-159.

Dothan, T. 1979. Excavations at the Cemetery of Deir el-Balah (Qedem 12). Jerusalem: Hebrew University of Jerusalem.

Dothan, T. 2008. Deir el-Balah: Uncovering an Egyptian outpost in Canaan from the time of the Exodus. Jerusalem: Israel Museum.

Eggler, J. and Keel, O. 2006. Corpus der Siegel-Amulette aus Jordanien: von Neolithikum bis zur Perserzeit. Freiberg: Academic Press.

Feldman, M. H. 2009. Hoarded Treasures: The Megiddo ivories and the end of the Bronze Age. Levant 41(2): 175-194. DOI: http://dx.doi.org.libproxy.ucl.ac.uk/10.1179/0075891 09X12484491671130

Finkelberg, M., Uchitel, A. and Ussishkin, D. 2004. The Linear A Inscription (LACH ZA 1). In Ussishkin, D. (ed.), Renewed Archaeological Excavations at Lachish (1973-1994), Volume 3. Tel Aviv: Tel Aviv University, 1629-1638.

Franken, H. J. 1992. Excavations at Tell Deir Alla: The Late Bronze Age sanctuary. Leuven: Peeters.

Gianto, A. 1999. Amarna Akkadian as a Contact Language. In van Lergerghe, K. and Voet, G. (eds), Languages and Cultures in Contact: At the crossroads of civilizations in the Syro-Mesopotamian realm. Leuven: Peeters, 123-132.

Giveon, R. 1985. Egyptian Scarabs from Western Asia from the Collections of the British Museum. Göttingen: Vandenhoeck and Ruprecht.

Goldwasser, O. 1984. Hieratic Inscriptions from Tel Sera' in Southern Canaan. Tel Aviv 11(1): 77-93.

Goldwasser, O. 1989. Some Egyptian Finds from Hazor: Scarabs, scarab impressions and a stele fragment. In Ben-Tor, A. (ed.), Hazor III-IV: An account of the third and fourth seasons of excavations, 1957-58, Text. Jerusalem: Israel Exploration Society, 339-345.

Goldwasser, O. 1991. An Egyptian Scribe from Lachish and the Hieratic Tradition of the Hebrew Kingdoms. Tel Aviv 18(2): 248-253.

Goldwasser, O. 2002. A 'Kirgipa' Commemorative Scarab of Amenhotep III from Beit Shean. Ägypten und Levante 12: 191-193.

Goldwasser, O. 2006. Canaanites Reading Hieroglyphs: Horus is Hathor? - The invention of the alphabet in Sinai. Ägypten und Levante 16: 121-160.

Goldwasser, O. and Wimmer, S. 1999. Hieratic Fragments from Tell El-Far'ah (South). Bulletin of the American Schools of Oriental Research 313: 39-42.

Goren, Y., Finkelstein, I. and Na'aman, N. 2004. Inscribed in Clay: Provenance study of the Amarna tablets and other ancient Near Eastern texts. Tel Aviv: Emery and Claire Yass Publications in Archaeology.

Goren, Y., Na'aman, N., Mommsen, H. and Finkelstein, I. 2006. Provenance Study and Re-evaluation of the Cuneiform Documents from the Egyptian Residency at Tel Aphek. Ägypten und Levant 16: 161-171. 
Hamilton, G. J. 2006. The Origins of the West Semitic Alphabet in Egyptian Scripts. Washington: Catholic Biblical Association of America.

Hamilton, G. J. 2010. The Early Alphabetic Inscription Painted on a Spouted Cup from Tell elAjjul. Maarav 17(2): 103-148.

Higginbotham, C. R. 2000. Egyptianization and Elite Emulation in Ramesside Palestine: Governance and accommodation on the imperial periphery. Leiden: E. J. Brill.

Horowitz, W. 1997. The Amarna Age Inscribed Clay Cylinder from Beth-Shean. Biblical Archaeologist 60(2): 97-100. DOI: http://dx.doi.org/10.2307/3210598

Horowitz, W., Oshima, T. and Sanders, S. 2006. Cuneiform in Canaan: Cuneiform sources from the land of Israel in ancient times. Jerusalem: Israel Exploration Society.

James, F. 1966. The Iron Age at Beth Shan: A study of levels VI-IV. Philadelphia: The University Museum, University of Pennsylvania.

James, F. and McGovern, P. E. 1993. The Late Bronze Egyptian Garrison at Beth Shan: A study of levels VII and VIII. Philadelphia: The University Museum, University of Pennsylvania.

Jeffreys, D. 2003. All in the Family? Heirlooms in Ancient Egypt. In Tait, J. (ed.), 'Never Had the Like Occurred': Egypt's view of its past. London: UCL Press, 197-211.

Keel, O. 1997. Corpus der Stempelsiegel-Amulette aus Palästina/Israel. Von den Anfängen bis zur Perserzeit. Katalog Band I: von Tell Abu Farag bis 'Atlit. Freiberg: Universitätsverlag Freiburg Schweiz.

Landsberger, B. and Tadmor, H. 1964. Fragments of Clay Liver Models from Hazor. Israel Exploration Journal 14(4): 201-218.

Macalister, R. A. S. 1912. The Excavation of Gezer, Volumes 1-3. London: Palestine Exploration Fund.

MacDonald, E., Starkey, J. and Lankester Harding, G. 1932. Beth Pelet II: Prehistoric Fara. London: British School of Archaeology in Egypt.

Maeir, A. M., Martin, M. and Wimmer, S. J. 2004. An Incised Hieratic Inscription from Tell esSafi, Israel. Ägypten und Levant 14: 125-134.

Magrill, P., Jasnow, R. and Kyle McCarter Jr., P. 2004. A Newly Discovered Egyptian Inscription. In Ussishkin; D. (ed.), Renewed Archaeological Excavations at Lachish (1973-1994), Volume 3. Tel Aviv: Tel Aviv University, 1618-1625.

McGovern, P. E. 1985. Late Bronze Palestinian Pendants: Innovation in a cosmopolitan age. Sheffield: American Schools of Oriental Research.

Millard, A. 1999. The Knowledge of Writing in Late Bronze Age Palestine. In van Lergerghe, K. and Voet, G. (eds), Languages and Cultures in Contact: At the crossroads of civilizations in the Syro-Mesopotamian realm. Leuven: Peeters, 317-326.

Moran, W. L. 1992. The Amarna Letters. Baltimore: John Hopkins University Press.

Mumford, G. D. 1998. International Relations Between Egypt, Sinai, and Syria-Palestine During the Late Bronze Age to Early Persian Period (Dynasties 18-26: c.1550-525 B.C.): A spatial and temporal analysis of the distribution and proportions of Egyptian(izing) artefacts and pottery in Sinai and Selected Sites in Syria-Palestine. Unpublished PhD dissertation, University of Michigan.

Oren, E. D. 1972. Tel Sera' (Tell esh-Sharia). Israel Exploration Journal 22: 167-169.

Oren, E. D. 1973. The Northern Cemetery at Beth Shan. Leiden: E. J. Brill.

Oren, E. D. Olivier, J. P., Goren, Y., Betancourt, P., Myer, G. H. and Yellin, J. 1996. A Minoan Graffito from Tel Haror (Negev, Israel). Cretan Studies 5: 91-117.

Parker, B. 1949. Cylinder Seals from Palestine. Iraq 11: 1-43.

Petrie, W. M. F. 1890. Kahun, Gurob and Hawara. London: Kegan Paul.

Petrie, W. M. F. 1930. Beth Pelet I. London: British School of Archaeology in Egypt.

Petrie, W. M. F. 1933. Ancient Gaza III. London: British School of Archaeology in Egypt. 
Petrie Museum of Egyptology. On-line Catalogue. http://www.petrie.ucl.ac.uk/index2.html [accessed on 19 May 2010].

Phillips, J. 1992. Tomb-robbers and their Booty in Ancient Egypt. In Orel, S. E. (ed.), Death and Taxes in the Ancient Near East. Lewiston/Queenston/Lampeter: Edwin Mellen Press, $157-192$.

Porter, B. and Moss, R. L. B. 1952. Topographical Bibliography of Ancient Egyptian Hieroglyphic Texts, Reliefs and Paintings VII: Nubia, the deserts, and outside Egypt. Oxford: Clarendon Press.

Richards, F. 2001. The Anra Scarab: An archaeological and historical approach (BAR International Series 919). Oxford: Archeopress.

Rothenberg, B. 1988. The Egyptian Mining Temple at Timna. London: Institute of Archaeology, University College London.

Sass, B. 1988. The Genesis of the Alphabet and Its Development in the Second Millennium B.C. Wiesbaden: Harrassowitz.

Schulman, A. R. 1993. A Ramesside Queen from Ashdod. Atiqot 23: 111-114.

Simpson, W. K. 2003. The Literature of Ancient Egypt: An anthology of stories, instructions, stelae, autobiographies and poetry. New Haven: Yale University Press.

Singer, I. 1977. A Hittite Hieroglyphic Seal Impression from Tel Aphek. Tel Aviv 4(3-4): 178-190. DOI: http://dx.doi.org.libproxy.ucl.ac.uk/10.1179/033443577788497696

Singer, I. 1988-1989. The Political Status of Megiddo VIIA. Tel Aviv 15-16(1): 101-112.

Singer, I. 1993. A Hittite Signet Ring from Tel Nami. In Rainey, A. F. (ed.), Kinattutu sa darati: Raphael Kutscher memorial volume. Tel Aviv: Institute of Archaeology.

Singer, I. 2003. Two Hittite Ring Seals from Tell el-Far'ah (South). Eretz-Israel 27: 133-134, $287^{\star}$.

Sparks, R. T. 2003. Egyptian Stone Vessels and the Politics of Exchange (2617-1070 BC). In Matthews, R. and Roemer, C. (eds), Ancient Perspectives on Egypt. London: UCL Press, 39-56.

Sparks, R. T. 2007. Stone Vessels in the Levant. Leeds: Maney Publishing.

Stewart, H. M. 1995. Egyptian Shabtis. Princes Risborough: Shire Publications.

Sweeney, D. 2003. A Lion-Hunt Scarab and Other Egyptian Objects from the Late Bronze Fortress at Jaffa. Tel Aviv 30(1): 54-65.

Sweeney, D. 2004. The Hieratic Inscriptions. In Ussishkin, D. (ed.), The Renewed Archaeological Excavations at Lachish (1973-1994), Volume 3 (Monographs of the Sonia and Marco Nadler Institute of Archaeology, Tel Aviv University 22). Tel Aviv: Emery and Claire Yass Publications in Archaeology, 1601-1617.

Teissier, B. 1996. Egyptian Iconography on Syro-Palestinian Cylinder Seals of the Middle Bronze Age (Orbis Biblicus et Orientalis 11). Göttingen: Vandenhoeck and Ruprecht.

Tufnell, O. 1958. Lachish IV: The Bronze Age. London: Oxford University Press.

Tufnell, O., Inge, C. H. and Harding, G. L. 1940. Lachish II: The Fosse Temple. London: Oxford University Press.

Ussishkin, D. 2004. Renewed Archaeological Excavations at Lachish (1973-1994), Volume 3. Tel Aviv: Tel Aviv University.

Ventura, R. 1987. Four Egyptian Funerary Stelae from Deir el-Balah. Israel Exploration Journal 37: $105-115$.

Ward, W. A. 1966. The Egyptian Inscriptions of Level VI. In James, F. (ed.), The Iron Age at Beth Shan: A study of levels VI-IV. Philadelphia: The University Museum, University of Pennsylvania, 161-179.

Weinstein, J. M. 1975. Egyptian Relations with Palestine in the Middle Kingdom. Bulletin of the American Schools of Oriental Research 217: 1-16.

Weinstein, J. M. 1981. The Egyptian Empire in Palestine: A reassessment. Bulletin of the American Schools of Oriental Research 241: 1-27. 
Wimmer, S. J. 1990. Egyptian Temples in Canaan and Sinai. In Israelit-Groll, S. (ed.), Studies in Egyptology presented to Miriam Lichtheim, Volume 2. Jerusalem: Magnes Press, Hebrew University, 1065-1106.

Wimmer, S. J. 2007. A Hieratic Sign. In Mazar, A. and Mullins, R. (eds), Excavations at Tel BethShean 1989-1996, Volume 2: The Middle and Late Bronze Age strata in Area R. Jerusalem: Israel Antiquities Authority, 688-689.

Yon, M. 2006. The City of Ugarit at Tell Ras Shamra. Winona Lake: Eisenbrauns. 